Stratigraphic Distribution of Significant Eocene Palynomorphs of the Mississippi Embayment

GEOLOGICALSURVEY PROFESSIONAL PAPER 743-B

Work done in cooperation with the

Kentucky Geological Survey

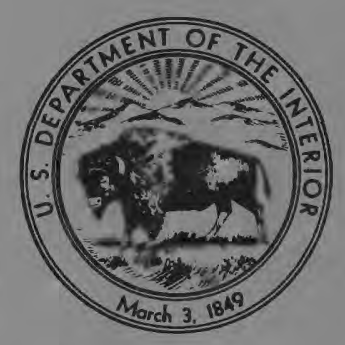




\section{Stratigraphic Distribution of Significant Eocene Palynomorphs of the Mississippi Embayment}

By ROBERT H. TSCHUDY

C O N T R I B U TIONS T O PALE ON T OL OGY

GEOLOGICAL SURVEY PROFESSIONAL PAPER $743-$ B

Work done in cooperation with the

Kentucky Geological Survey

Palynomorph assemblages characterizing

formations within the Wilcox, Claiborne, and Jackson Groups

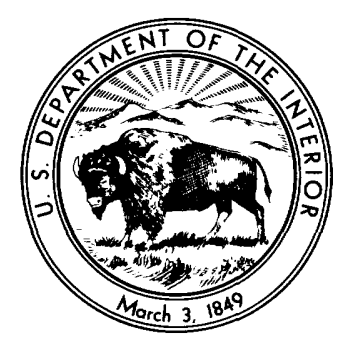

$\overline{\text { UNITED STATES GOVERNMENT PRINTING OFFICE, WASHINGTON : } 1973}$ 
UNITED STATES DEPARTMENT OF THE INTERIOR

ROGERS C. B. MORTON, Secretary

\section{GEOLOGICAL SURVEY}

V. E. McKelvey, Director

Library of Congress catalog-card No. 72-600318

For sale by the Superintendent of Documents, U.S. Government Printing Office, Washington, D.C. 20402

Price 75 cents domestic postpaid, or 55 cents GPO Bookstore Stock Number 2401-00271 


\section{CONTENTS}
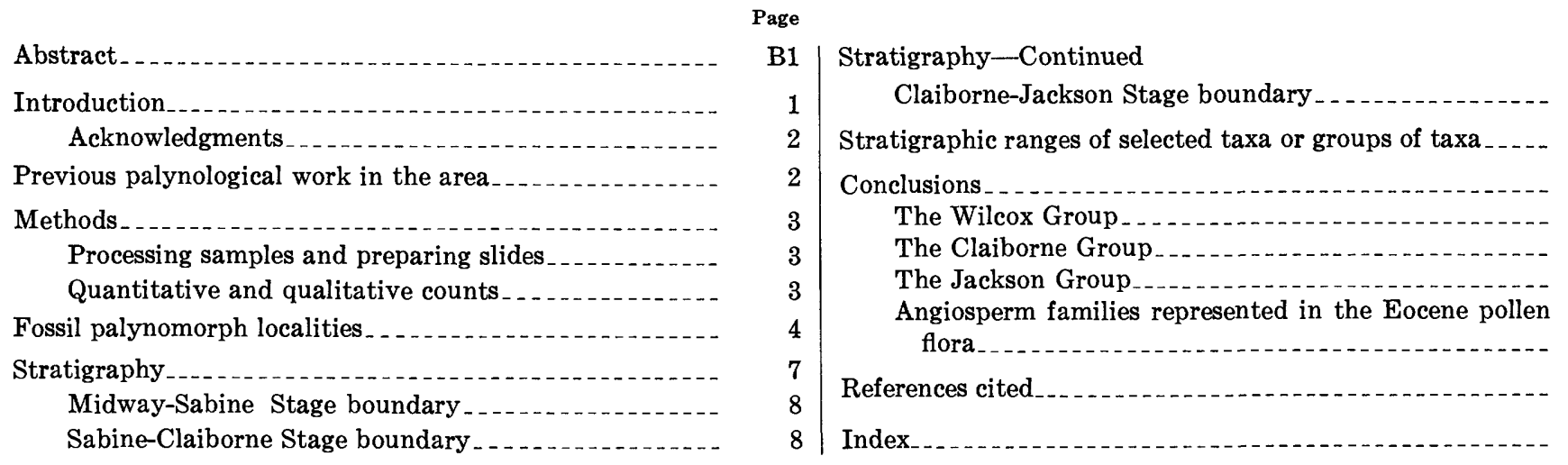

Page
B8
9
18
18
18
18
19
19
23

\section{ILLUSTRATIONS}

[Plates follow index]

Plate 1. Pollen from the Wilcox Group.

2. Pollen from the Wilcox and Claiborne Groups.

3. Pollen and spores from the Claiborne and Jackson Groups.

4. Pollen and other fossils from the Claiborne and Jackson Groups.

FIGURE 1. Generalized geologic map of Mississippi embayment showing fossil localities

2. Chart showing stratigraphic distribution and relative abundance of selected taxa

\section{TABLES}

TABLE 1. Summary of palynological work in the Mississippi embayment region

2. Stratigraphic columns

3. Eocene stratigraphic units from which samples were obtained

4. Angiosperm families represented by pollen reported from the Mississippi embayment region. 


$$
\text { . }
$$




\title{
STRATIGRAPHIC DISTRIBUTION OF SIGNIFICANT EOCENE PALYNOMORPHS OF THE MISSISSIPPI EMBAYMENT
}

\author{
By RoBerT H. TSCHudy
}

\begin{abstract}
The stratigraphic occurrences are given for about 45 of the more significant plant microfossil types from some well-documented reference localities in the Mississippi embayment area of Alabama, Mississippi, Louisiana, Texas, and Arkansas. Rocks of the Wilcox, Claiborne, and Jackson Groups of Eocene age can be differentiated on the basis of their plant microfossil content. The palynological change between the Wilcox and Claiborne Groups is easily recognized by the abrupt termination of several species and by the first occurrences of other species. The palynological change from the Claiborne Group to the Jackson Group is not as abrupt as that from the Wilcox Group to the Claiborne Group. A Claiborne-Jackson pollen transition zone, corresponding somewhat to the lithological transition zone, is recognized in the upper part of the Cockfield Formation of the Claiborne Group.

Before any inferences concerning evolutionary or climatic aspects of a fossil flora can be made, some knowledge of the modern counterparts of the flora whose ecological tolerances are known must be available.
\end{abstract}

\section{INTRODUCTION}

The stratigraphic differentiation of the Eocene by means of palynomorphs presented herein was derived from work done on the Kentucky cooperative mapping project. At the inception of the project, few palynological studies of Mississippi embayment rocks were available. In order to obtain adequate stratigraphic control it was therefore necessary to obtain palynological assemblages from type or well-documented formations from within this depositional basin. These reference assemblages were used as comparison material for the dating and interpretation of samples of unknown ages submitted by geologists working on the Kentucky cooperative mapping project.
Reference samples were obtained from formations representing the Upper Cretaceous, Paleocene, Eocene, Oligocene, and Miocene. In this paper, however, discussion will be restricted to Eocene reference samples.

Complete agreement on the absolute chronology of purported Eocene formations in the Mississippi embayment area has not been attained. For example, the lower part of the Wilcox Group is considered by Berggren (1965) to be of Paleocene age on the basis of planktonic Forminifera. Berggren (1965, p. 280) stated "The stage names Midway, Sabine and Claiborne commonly used in Gulf Coast stratigraphy do not correspond to the classic time-stratigraphic subdivisions in western Europe. The practice of placing the PaleoceneEocene boundary at the base of the Sabine Stage (also called Wilcox Stage by some) is discouraged." Furthermore, the terminology applied to the Eocene formations is not uniform throughout the area. This lack of uniformity is demonstrated in table 2. There is, however, general agreement concerning the subdivision of Eocene rocks into three groups of formations, the lower Eocene Wilcox Group which may be locally Paleocene and locally middle Eocene, the middle Eocene Claiborne Group, and the upper Eocene Jackson Group.

For the purposes of this report, the absolute chronology of the several formations is of secondary importance. Agreement on the absolute dates assignable to the formations and groups will gradually evolve. The intent here is to provide palynological biostratigraphic control from the formations embraced by the Wilcox, Claiborne, and Jackson Groups (as generally accepted by the U.S. Geological Survey). The data presented 
herein will serve as a preliminary basis for the identification of the various segments of Eocene rocks represented in the Mississippi embayment region.

Only the more abundant or the more significant palynomorphs are discussed. These are arranged into 45 species or groups. The 45 species or groups represent only a fraction of the more than 370 taxa from these rocks that are at present recognized by the USGS Palynological laboratory, Denver, Colo.

\section{ACKNOWLEDGMENTS}

I express my appreciation to those who assisted in this study. W. W. Olive, H. N. Halberg, E. H. Boswell, and B. R. Haley, all of the U.S. Geological Survey, assisted in obtaining reference samples from the Mississippi embayment. Mr. W. W. Fairchild of the Standard Oil Co. of Texas supplied samples from the Pendleton, Reklaw, and Sparta Formations. The Mississippi Geological Survey supplied core samples of the Yazoo Clay. Sharon Van Loenen and Kathryn Dieterich prepared the samples and photographed the fossils.

\section{PREVIOUS PALYNOLOGICAL WORK IN THE AREA}

Probably the first reference to pollen and spores from Mississippi embayment rocks is that of Thiessen (in White and Thiessen, 1913). Thiessen discussed the structure of thin sections of coals as seen under the microscope. He observed coals from near Lester, Ark., and lignites from Rockdale and Hoyt, Tex. Not only did he observe pollen and spores in thin section-"The spores are of great variety in kind and size $* * *$ Pollen grains are rather numerous, seemingly both of angiosperms and gymnosperms" (Thiessen, in White and Thiessen, 1913 , p. 234) - but he also macerated sections of coal chemically and was able to observe the pollen and spores in entirety, rather than sectionally as they appeared in the thin sections of coal. He (p. 235) stated,

The very large number of spore exines may be best appreciated when sections cut by the ordinary method are subsequently treated with Schulze's reagent and dissolved under the microscope. In sections cut at right angles to the bedding, one looks at the edges of the spores, like filter paper standing on edge, but as the dissolution goes on, and by tapping gently on the cover glass, one may readily see them separate and fall over on the side. In this position their true spore or pollen nature can be readily recognized, because of the tetrasporic ridges or exterior sculpturing.

Thiessen did not attempt a detailed examination and description of the pollen and spores.

Unpublished theses by McLaughlin on the Wilcox of Louisiana and on the Bruhn lignite in Henry County, Tenn., were submitted in 1952 and 1957, respectively. By projecting regional dips, McLaughlin tentatively placed the lignite from Tennessee in the Upper Cretaceous. Through the courtesy of Dr. Elso Barghoorn of Harvard University, I was able to examine a copy of the 1957 thesis. The assemblage is definitely of Eocene age, rather than of Cretaceous, as Fairchild and Elsik (1969) also have noted.

Two publications appeared in 1960. Gray (1960) discussed pollen genera from the Gosport Sand of the Claiborne Group in Alabama. She identified families and genera in the assemblage with modern genera and suggested that the flora indicated a more temperate environment than the earlier Eocene floras. Krutzsch (1960a) described the genus Thomsonipollis from the Wilcox near Austin, Tex., and from the lower Eocene of middle Europe.

Jones (1961a, 1962), on the basis of his unpublished $\mathrm{Ph}$. D. dissertation (1961a), discussed the palynology of the Midway-Wilcox boundary in Arkansas and the environmental significance of the palynological assemblages. The Eocene flora was supposedly from the Saline Formation of the Wilcox Group. Fairchild and Elsik (1969), in their discussion of Jones' assemblage, reported "The assemblage from the Saline Formation of the Wilcox Group in Arkansas illustrated by Jones *** also has a typically middle Eocene aspect." Recent work in this laboratory indicates that the Saline Formation is middle Eocene rather than early Eocene.

The first published assemblage of palynomorphs from the Mississippi embayment was presented by Engelhardt (1964a). He illustrated the fossil pollen and spores from the Cockfield Formation of Mississippi. In the same year (1964b), he described a new species of Gothanipollis from the middle Eocene of Mississippi.

In 1965, a $\mathrm{Ph}$. D. thesis (Warter, 1965) described the pollen flora from the Tuscahoma Formation of the Wilcox Group from Mississippi. In the thesis, she listed 89 species, 52 of which she assigned to modern genera. She also recorded the presence of four genera from the Normapolles Group, originally described from Europe.

Reflections of the diversity of flora in the Eocene of the area and of the lack of taxonomic studies are seen in the report by Stover, Elsik, and Fairchild (1966). They described 10 new genera and 13 new species of palynomorphs from the Gulf Coast Tertiary.

The first detailed attempts at taxonomic treatment of palynomorphs from this area were published by Elsik (1968a, b). He obtained his material from lignite in the Rockdale Formation of the Wilcox Group in Texas. His taxonomic treatment revealed a close similarity of his assemblage to Eocene assemblages from Europe. This similarity is perhaps accentuated by his practice of grouping specimens of similar morphology. Elsik (1968a, p. 266) stated "a great diversity of form and preservation of the angiosperm pollen justifies morphologic groupings rather than detailed speciation."

The only strictly stratigraphic evaluation of palynomorphs from this region is in the paper by Fairchild 
and Elsik (1969). They summarized the stratigraphic ranges of some of the more significant genera and species found in the Gulf Coast Eocene and compared these ranges with the ranges of identical genera and species reported by Krutzsch $(1957,1960 \mathrm{~b})$ and Kedves (1967). Fairchild and Elsik (p. 87) claimed that "nonmarine Lower Tertiary formations of the Gulf Coast can be correlated by palynology, and that many of the wellknown stratigraphically restricted European species do occur in the Gulf Coast in essentially the same sequence."

Palynomorphs of the Jackson Group have received little attention. Tschudy and Van Loenen (1970) illustrated plant microfossils from the Yazoo Clay of Mississippi, and Frederiksen (1970) submitted a thesis on the stratigraphy and palynology of the Jackson Stage of Mississippi and Alabama. Through the courtesy of Norman Frederiksen, I was able to obtain reproductions of his plates. His assemblage is virtually the same as assemblages I found in several samples from the lower part of the Jackson.

Published palynological work on the Eocene of the Mississippi embayment region is very scanty and does not attempt to present the floras and floral changes in any detail. As may be seen from the summary table (table 1), most of the work has been concentrated on parts of the Wilcox Group, and no attempt has been made to characterize palynologically the Wilcox, Claiborne, and Jackson Groups or to show the palynological changes that occur within or between these groups. The purpose of this report is to partly eliminate this hiatus in palynological data.

\section{METHODS}

\section{PROCESSING SAMPLES AND PREPARING SLIDES}

Samples were prepared for examination by a standardized method presented by Tschudy (1970, p. F2).

\section{QUANTITATIVE AND QUALITATIVE COUNTS}

The prepared slides were examined in detail as follows: Counts were made of identifiable taxa of pollen and spores to obtain an estimate of the relative abundance of the species. Counts were made including spores and marine fossils (acritarchs and dinoflagellates) until a minimum of 200 identified angiosperm specimens had been noted. This count provided an estimate of the relative abundance of the more common taxa and provided a means of estimating the ratio of spores or other fossils to angiosperm pollen.

Some samples contain a great number of distinguishable species or distinctive forms. For these, the percentage count commonly does not record all the different palynomorphs present. It therefore became necessary to examine the slides in greater detail, recording all distinct palynomorphs. As a result, many taxa not
TABLE 1.-Summary of palynological work in the Mississippi embayment region

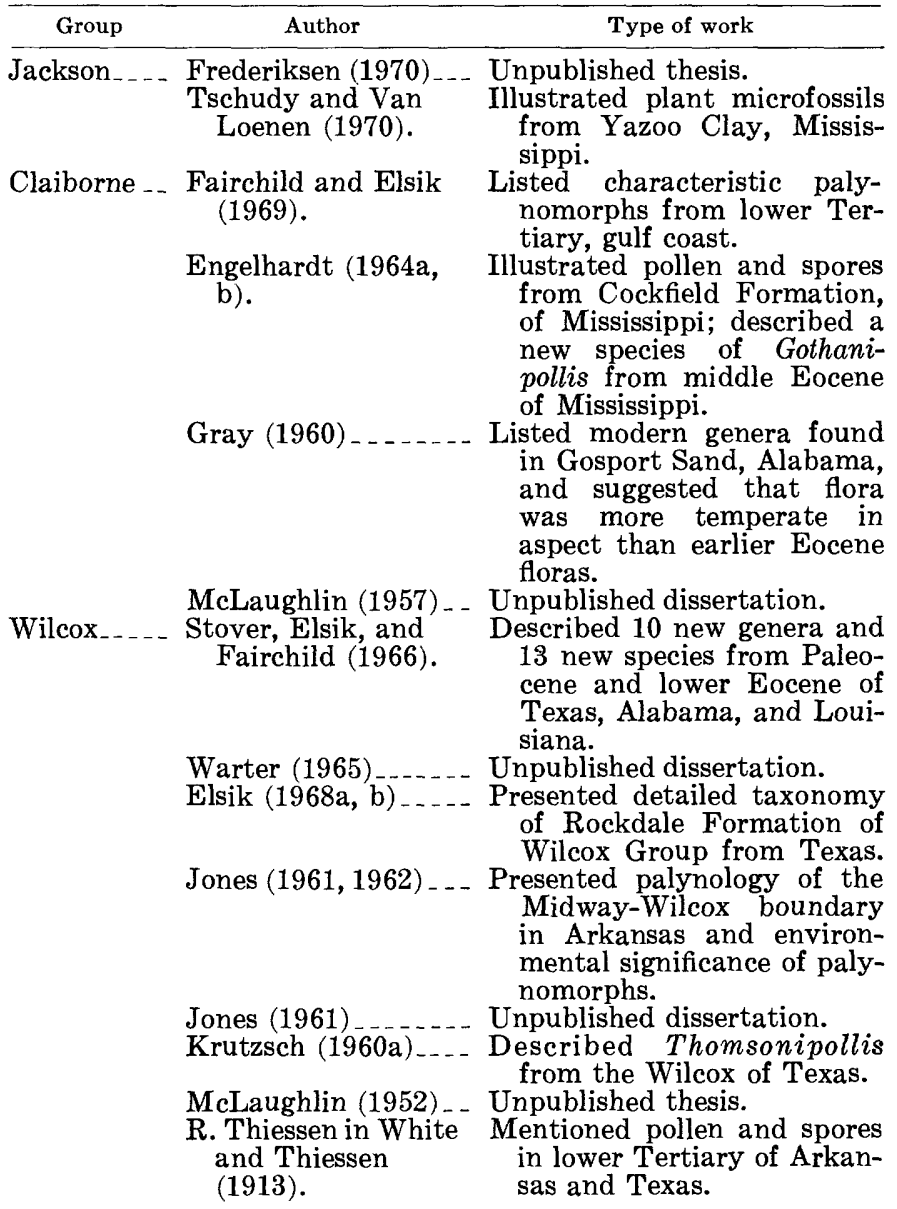

present in the initial count were recorded. The stratigraphic ranges of some of the more significant species were thus more closely approximated. If, for example. a count of 200 is made on a slide that contains 10,000 or more pollen grains (a common occurrence), species that may be consistently present in such samples may be overloooked if only the initial count is recorded. A further reason for continuing examination of slides after the percentage count has been made is that some longranging taxa may, on some slides, occur in abundance. In some slides, specimens of such taxa may make up more than 75 percent of the total pollen. Very little information of stratigraphic value would be obtained from such samples if the examination for rare or less common taxa were omitted.

After counts had been made and the less common taxa recorded, the data were plotted. From these preliminary charts, the most significant data were extracted and plotted on a résumé chart. This chart (fig. 2) shows the stratigraphic range and relative abundance of 45 taxa or groups of taxa. This number represents but a fraction of the total number of units 
recorded. One sample yielded more than 80 different species. In the entire sequence from Wilcox through Jackson, more than 370 species were recognized. Most of these species are not yet recorded in the palynological literature. Those that have been reported have had little or no discussion of their stratigraphic ranges or their stratigraphic importance.

The taxa recorded in figure 2 are shown on plates $1-4$. The plates are provided as an additional means of identification of the groups considered. Furthermore, they provide some data concerning the morphological variations included in the groups. This method (fig. 2) of recording the stratigraphic distribution of Tertiary palynomorphs has been used by Krutzsch (1957, 1960b), by Kedves (1967) and by others to present useful stratigraphic data before all the details of taxonomy and nomenclature have become available.

Some species and groups of species have been recorded on the graph; examples are the species Maceopolipollenites tenuipolus and the group Tricolporopollenites spp. of the T. baculoferus type. Some genera only have been considered (Thomsonipollis and Kyandopollenites). In one instance, only the family-the Gramineae (grass family)-is recorded.

All specimens illustrated in this report are deposited in the slide files of the paleobotanical collections of the U.S. Geological Survey, Denver, Colo.

\section{FOSSIL PALYNOMORPH LOCALITIES}

The rock samples used for obtaining palynomorph reference material from the Eocene of the Mississippi embayment are from the localities shown in figure 1. The formations examined, as well as the U.S. Geological Survey Paleobotany locality numbers, are shown on this map.

The detailed descriptions of localities in approximate stratigraphic order, oldest to youngest, are given in the following list.

\begin{tabular}{ccc}
\hline $\begin{array}{c}\text { USGS } \\
\text { Paleobotany } \\
\text { loc. }\end{array}$ & \multicolumn{1}{c}{ Locality } & Stratigraphic unit \\
\hline D3222_... & $\begin{array}{r}0.2 \text { of a mile east of bridge } \\
\text { across Tucabum River on } \\
\text { Lavaca-Pennington Road } \\
\text { on south side of new }\end{array}$ & $\begin{array}{r}\text { Nanafalia Formation. } \\
\text { In Wilcox Group. }\end{array}$ \\
& $\begin{array}{l}\text { roadcut, sec. 22, T. 14 N., } \\
\text { R. 1 W., Choctaw County, }\end{array}$ & \\
& Ala. (See MacNeil, geo- & \\
& logic map, 1946a.) Col- & \\
& lected by W. W. Olive and & \\
R. H. Tschudy, U.S. Geo- & \\
logical Survey, 1963. & \\
D1854_.-- About 1 mile northeast of & Wilcox Formation \\
Ackerman, Miss., in rail- & (formerly Acker- \\
road cut, Illinois Central & man Formation, \\
Railway, at Blantons Gap, & type locality).
\end{tabular}

\begin{tabular}{|c|c|c|}
\hline $\begin{array}{c}\text { USGS } \\
\text { Paleobotany } \\
\text { loc. }\end{array}$ & Locality & Stratigraphic unit \\
\hline & $\begin{array}{l}\text { R. } 11 \text { E., Choctaw County, } \\
\text { Miss. (See Vestal, 1943, p. } \\
\text { 30.) Collected by W. W. } \\
\text { Olive, U.S. Geological Sur- } \\
\text { vey, } 1962 .\end{array}$ & \\
\hline D1862 . & $\begin{array}{l}\text { From south wall of the valley } \\
\text { of Potts Creek, about } 75 \\
\text { yards east of road bridge, } \\
\text { NW1/4 sec. 4, T. } 6 \text { S., R. } \\
1 \text { W., Marshall County, } \\
\text { Miss. (See Vestal, 1954, p. } \\
\text { 41.) Collected by W. W. } \\
\text { Olive, U.S. Geological Sur- } \\
\text { vey, } 1962 \text {. }\end{array}$ & $\begin{array}{l}\text { Wilcox Formation } \\
\text { (formerly Acker- } \\
\text { man Formation). }\end{array}$ \\
\hline D1846 _ & $\begin{array}{l}\text { Sample F-48, NW } 1 / 4 \mathrm{SE} 1 / 4 \\
\text { sec. 12, T. } 6 \text { N., R. } 13 \text { W., } \\
\text { Sabine Parish, La., elev } \\
165 \text { ft. (See Andersen, } \\
1960 \text {, p. } 74,75 \text {, fig. 13.) } \\
\text { Supplied through the cour- } \\
\text { tesy of W. W. Fairchild, } \\
\text { Standard Oil Co. of Texas, } \\
1962 .\end{array}$ & $\begin{array}{l}\text { Bayou Lenann Mem- } \\
\text { ber of Pendleton } \\
\text { Formation (type } \\
\text { locality) of Ander- } \\
\text { sen, 1960. In Wil- } \\
\text { cox Group. }\end{array}$ \\
\hline D1851 _ & $\begin{array}{l}\text { Sample F-129 from north } \\
\text { side of Louisiana State } \\
\text { Highway } 6 \text {, sec. } 6, \text { T. } 6 \text { N., } \\
\text { R. } 11 \text { W., Sabine Parish, } \\
\text { La. Ostrea multilirata zone. } \\
\text { (See Andersen, 1960, p. } \\
\text { 76.) Supplied through the } \\
\text { courtesy of W. W. Fair- } \\
\text { child, Standard Oil Co. of } \\
\text { Texas, } 1962 \text {. }\end{array}$ & $\begin{array}{l}\text { Pendleton Formation } \\
\text { (of Andersen, } \\
\text { 1960). In Wilcox } \\
\text { Group. }\end{array}$ \\
\hline D1855 _ & $\begin{array}{l}\text { North side of roadcut } 1.5 \\
\text { miles west of corporate } \\
\text { limit of Meridian, Miss., } \\
\text { on U.S. Highway } 80 \text {, secs. } \\
\text { 15, 22, T. } 6 \text { N., R. } 15 \text { E., } \\
\text { Lauderdale County, Miss. } \\
\text { (See Foster, 1940, p. 67.) } \\
\text { Collected by W. W. Olive, } \\
\text { U.S. Geological Survey, } \\
\text { 1962. }\end{array}$ & $\begin{array}{l}\text { Uppermost part, } \\
\text { Hatchetigbee For- } \\
\text { mation. In Wilcox } \\
\text { Group. }\end{array}$ \\
\hline D184 & $\begin{array}{l}\text { Sample F-71, from bed of } \\
\text { Two Mile Creek, } 1.5 \text { miles } \\
\text { due south of U.S. Highway } \\
79 \text { bridge across Brazos } \\
\text { River, Milam County, } \\
\text { Tex. (Stop } 2 \text { of Houston } \\
\text { Geol. Soc. Ann. Field Trip, } \\
\text { 1959. (See Smith, 1959.) } \\
\text { Supplied through the cour- } \\
\text { tesy of W. W. Fairchild, } \\
\text { Standard Oil Co. of Texas, } \\
1962 .\end{array}$ & $\begin{array}{l}\text { Marquez Shale Mem- } \\
\text { ber (of Stenzel, } \\
\text { 1938) of Reklaw } \\
\text { Formation. In } \\
\text { Claiborne Group. }\end{array}$ \\
\hline D1858_ & $\begin{array}{l}\text { Holly Springs Brick and Tile } \\
\text { Co., Holly Springs, Miss., } \\
\text { pit south of Highway } 78,\end{array}$ & $\begin{array}{l}\text { Tallahatta Forma- } \\
\text { tion. In Claiborne } \\
\text { Group. }\end{array}$ \\
\hline
\end{tabular}
$\mathrm{SE} 1 / 4$ sec. 26 , T. 3 S., R. 3 W., Marshall County, Miss. (See Vestal, 1954, 


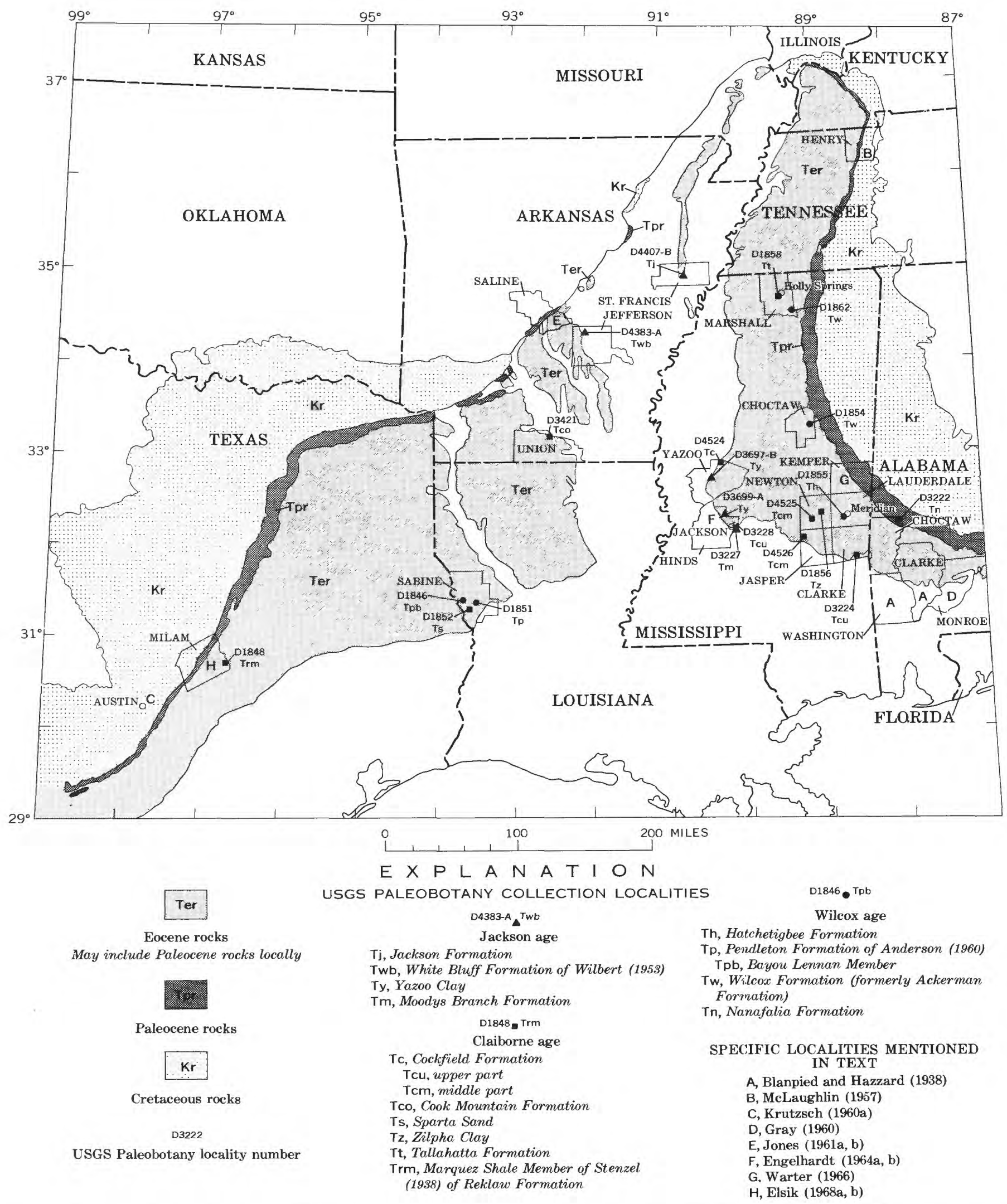

FiguRE 1.-Generalized geologic map of Mississippi embayment showing fossil localities. Modified from geologic map of the United States, 1932. 


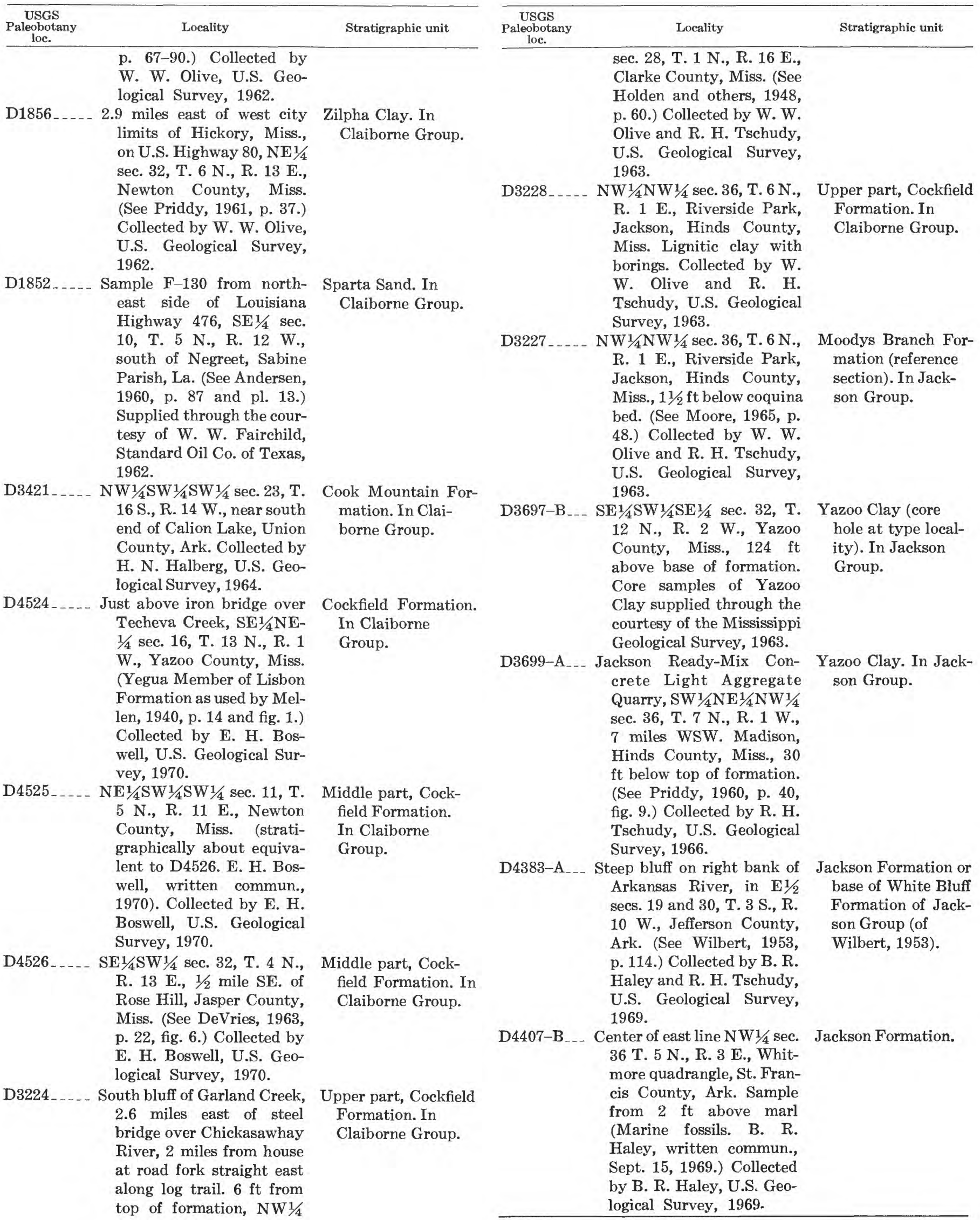




\section{STRATIGRAPHY}

The Eocene Series in the Mississippi embayment consists, in ascending order, of the Wilcox (part) Group or Formation, the Claiborne Group, and the Jackson Group or Formation. The Eocene is underlain by the Paleocene. Samples from the Clayton Formation, the Porters Creek Clay, the Wills Point Formation, and the Naheola Formation of the Midway Group, and the Naborton Formation of the Wilcox Group, all of the Paleocene Series, have been examined palynologically and can be distinguished from rocks assigned to the Eocene Series by their content of pollen and spores. Inasmuch as it was desirable to differentiate Eocene rocks palynologically and to recognize stages within the Eocene, definitions of the generally accepted boundaries and the formations of these ages had to be determined. Table 2 shows the stratigraphic columns recognized for the Eocene units in the area of study.

Eocene Series:

TABLE 2.-Stratigraphic columns ${ }^{1}$

$$
\text { Northeastern Texas }
$$

Claiborne Group

Sparta Sand

Weches Greensand

Queen City Sand

Reklaw Formation

Carrizo Sand

Wilcox Formation

Paleocene Series

Eocene Series:

Jackson Group:

Yazoo Clay

Moodys Branch Formation

Claiborne Group:

Cockfield Formation

Cook Mountain Formation

Sparta Sand

Cane River Formation

Carrizo Sand

Eocene and Paleocene Series:

Wilcox Group: ${ }^{2}$

Dolet Hills Formation

Naborton Formation

Paleocene Series

Eocene Series:

Jackson Group, undifferentiated

Claiborne Group:

Cockfield Formation

Cook Mountain Formation

Sparta Sand

Cane River Formation

Carrizo Sand

Wilcox Group undifferentiated ${ }^{3}$

Paleocene Series

Eocene Series:

Wilcox Formation

Paleocene Series

Missouri

Eocene Series:

Wilcox Group, undifferentiated

Paleocene Series
TABLE 2.-Stratigraphic columns ${ }^{1-C o n t i n u e d}$

Kentucky

Eocene Series:

Jackson Formation

Claiborne Group, undifferentiated

Wilcox Group, undifferentiated

Paleocene Series

Eocene Series:

Jackson Formation

Claiborne Group:

Cockfield Formation

Cook Mountain Formation

Tallahatta Formation:

Basic City Shale Member

Meridian Sand Member

Memphis Sand

Wilcox Group:

Flour Island Formation

Fort Pillow Sand

old Breastworks Formation

Paleocene Series

Northern Mississippi

Eocene Series:

Jackson Group, undifferentiated

Claiborne Group:

Cockfield Formation

Cook Mountain Formation

Sparta Sand

Zilpha Clay

Winona Sand

Tallahatta Formation

Wilcox Formation

Holly Springs Sand Member

Paleocene Series

Northern Mississippi

Eocene Series: (southern part)

Jackson Group, undifferentiated

Claiborne Group:

Cockfield Formation

Cook Mountain Formation

Sparta Sand

Zilpha Clay

Winona Sand

Tallahatta Formation

Wilcox Formation

Paleocene Series

Eocene Series:

Jackson Group:

Yazoo Clay:

Shubuta Member

Pachuta Marl Member

Cocoa Sand Member

North Creek Member

Moodys Branch Formation

Claiborne Group:

Cockfield Formation

Cook Mountain Formation: Gordon Creek Shale Member

Potterchito Sand Member

Archusa Marl Member

Sparta Sand

Zilpha Clay

Winona Sand

Tallahatta Formation

Neshoba Sand Member

Basic City Shale Member

Meridian Sand Member

\footnotetext{
${ }^{1}$ Modified from Cushing, Boswell, and Hosman (1964, table 1, p. B6). 2 Wilcox Group (Eocene Series, undifferentiated). Wilcox Group (Paleocene Series), upper part undifferentiated; Dolet Hills and Naborton Formations lower two units.

${ }^{3}$ In ascending order, Wilcox Group in bauxite area of Arkansas comprises Berger Formation, Saline Formation, and Detonti Sand.
} 
TABLE 2.-Stratigraphic columns ${ }^{1}$-Continued Central Mississippi-Continued

Wilcox Formation:

Bashi Marl Member

Fearn Springs Member

Paleocene Series

Eocene Series:

Claiborne Group:

Tallahatta Formation

Meridian Sand Member

Wilcox Group

Hatchetigbee Formation:

Bashi Marl Member

Tuscahoma Sand

Bells Landing Marl Member

Greggs Landing Marl Member

Nanafalia Formation:

Grampion Hills Member

Middle member

Paleocene Series

Gravel Creek Sand Member

${ }^{1}$ Modified from Cushing, Boswell, and Hosman (1964, table 1, p. B6).

MIDWAY-SABINE STAGE BOUNDARY

The Midway Stage, as defined by Murray (1961, p. $367)$,

*** is employed as a time-rock unit containing all deposits in the Gulf and Atlantic coastal province which can be demonstrated reasonably accurately to be equivalent to the type Midway and its typical sedimentary units (Clayton Formation, Porters Creek Clay, Naheola Formation and associated deposits). This effectively includes all the Tertiary deposits formed in the Gulf and Atlantic coastal province prior to deposition of the widespread beds containing Ostrea thirsae or Ostrya multilirata in east Texas, Louisiana, Mississippi and Alabama, and their equivalents.

Wilcox has been used as a time-stratigraphic or stage term, and also as a rock-stratigraphic term, though the use of the name Wilcox as a rock-stratigraphic term has precedence. This dual usage, which does not embrace rocks of the same age, has caused considerable confusion. Recognizing this situation, Murray (1955) included in the Wilcox Group similar rock units of both Paleocene and early Eocene age and suggested the term Midway Stage for formations of Paleocene age and the term Sabine Stage for formations of early Eocene age.

A diagrammatic representation of time and rock relations of the Midway and Sabine Stages and the Midway and Wilcox Groups is given by Murray (1955, p. 684).

The basal formation examined and discussed in this report is the Nanafalia Formation, and the uppermost formation of the Wilcox Group examined and discussed is the Hatchetigbee Formation.

\section{SABINE-CLAIBORNE STAGE BOUNDARY}

Much less nomenclatural confusion exists for the Claiborne sequence than for the Wilcox. The Claiborne Group as used by the U.S. Geological Survey is equivalent in age to the Claiborne Stage of Murray (1961, p. 380). The basal formations of the Claiborne Group examined palynologically are the Reklaw and Tallahatta, and the uppermost is the Cockfield. (See discussion under "Claiborne-Jackson Stage Boundary".) The Claiborne Stage $* * *$ has come to be used as a time-rock division of the Eocene in the coastal province to include a great variety of lithologic types unified by a common age as determined by fossil content" (Murray, 1961, p. 380).

The Claiborne Group embraces all beds that were deposited from the beginning of the initial invasion of the Claiborne Sea, and it involves several cyclic depositional units. Regressive strata consisting of argillaceous, arenaceous, and carbonaceous to lignitic beds terminate the sequence; marine transgressive strata were then deposited by the advancing Jackson Sea.

\section{CLAIBORNE-JACKSON STAGE BOUNDARY}

A detailed discussion of the Jacksonian Stage is given by Murray and Wilbert (1950, p. 1995).

The Jacksonian Stage as here conceived, therefore, is a time-rock unit which embraces all sediments deposited during the time occupied by the advance and retreat of the late Eocene sea in the Gulf and Atlantic coastal region. In this view, the earliest sediment which can be associated definitely with the advance of this sea, or can be found to have been deposited during the time the sea was advancing, becomes Jacksonian; the latest stratum which can be tied to the retreat of this sea is included likewise.

The basal formation in the Jackson Group is generally recognized in Alabama, Georgia, Mississippi, and Louisiana as the Moodys Branch Formation. The Moodys Branch is distinctive and provides one of the better mappable units. It is definitely of marine origin, consisting of limestone and glauconitic sandy marl. It includes the transition zone (Blanpied and Hazzard, 1938, p. 313), which consists of black carbonaceous shale similar to the shales of the underlying Cockfield Formation, but which contains thin partings and lenses of fossiliferous glauconitic marl. The transition zone was found to be $0-20$ feet thick in wells in Washington and Clark Counties, Ala. The foraminiferal assemblages from these partings are of Jackson age. Reference to a transition zone between the Moodys Branch and the Cockfield Formations persists in the literature. "The lower member [of Moodys Branch Formation] is interpreted as a transitional facies from probable pro-del taic deposition in the Upper Claiborne Stage, to off-shore, shallow marine deposition in the Lower Jacksonian" (DeVries, 1963, p. 24).

The Moodys Branch Formation is abundantly fossiliferous. The formation marks the marine transgression of the advancing Jackson Sea, however, in some areas this marine transgression was not abrupt. Evidence of marine or brackish sediments is present in some areas in rocks of the lignitic Cockfield, which underlies the Moodys Branch. The nature of the Moodys Branch-Cockfield contact in Sabine Parish, La., is discussed by Treadwell (1954, p. 2307); the Cockfield is 
divided by him into an upper brackish or marginal marine facies - the Creola Member-and an underlying deltaic limnic facies. Units belonging to the marine Creola Member have been measured to a depth of 47 feet in Sabine Parish, La., where the Cockfield is about 800 feet thick. Treadwell (1954, p. 2320) concluded

The Moodys Branch-Cockfield contact exhibits several variations in Sabine Parish. Nevertheless, available evidence suggests there was a break in most places between the deposition of these two formations. This interruption was small and in Sabine Parish should be considered diastemic.

The first samples obtained for the palynological characterization of the Cockfield Formation were collected from the Cockfield immediately below the Cockfield-Moodys Branch contact at the Moodys Branch reference locality in Riverside Park, Jackson, Miss. (sample D3228), and at a similar locality on Garland Creek, Clarke County, Miss. (sample D3224). These two samples yielded pollen floras that were more like the Jackson floras than the floras of the underlying Claiborne Group. Because the Riverside Park and the Garland Creek samples were collected immediately below the top of the Cockfield Formation, they were thought to represent the transition zone. Huff (1970, p. 26) says: "In the Garland Creek section in Clarke County near Shubuta there is a large massive lignitic sand unit below the Moodys Branch called the "Transition Zone."' In order to obtain a better coverage of the flora of the Cockfield, and to learn whether a palynological transition zone was present in the upper part of the Cockfield, I obtained and examined additional samples from the middle and lower parts of the Cockfield. Eocene stratigraphic units from which palynological reference samples were obtained are shown in table 3 .

\section{STRATIGRAPHIC RANGES OF SELECTED TAXA OR GROUPS OF TAXA}

The observed stratigraphic ranges and the relative abundance of the more significant genera and species appearing in the control samples from the Wilcox, Claiborne, and Jackson Groups are shown in figure 2. The formations are shown in stratigraphic order, but the vertical spacing of the formations is arbitary. Widths of bars denote categories of frequency of occurrence of taxa which were arbitrarily selected to minimize minor fluctuations from sample to sample. Both uninterrupted and interrupted ranges of these units will undoubtedly be extended by data from further work.

Each taxon represented in figure 2 is discussed oldest to youngest.

Fossil pollen assemblages from the Mississippi embayment contain many hitherto undescribed species,
TABLE 3-Eocene stratigraphic units from which samples were obtained

Stratigraphic unit as identified Stratigraphic unit as recognized by collector by U.S. Geological Survey

Jackson Group:

White Bluff Formation 1 - _. . - Jackson Formation.

Yazoo Clay ........ Yazoo Clay.

Moodýs Branch Formation_._. Moodys Branch Formation. Claiborne Group:

Cockfield Formation _........ Cockfield Formation.

Yegua Member, Lisbon For-

mation 2 ......... Cockfield Formation, lower part.

Cook Mountain Formation _. _ Cook Mountain Formation.

Sparta Sand.............. Sparta Sand.

Zilpha Clay.................. Zilpha Clay.

Tallahatta Formation...... Tallahatta Formation.

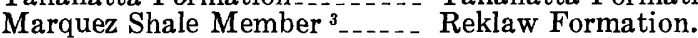

Reklaw Formation . Do.

Wilcox Group:

Hatchetigbee Formation _. . . . Hatchetigbee Formation.

Pendleton Formation ${ }^{4} \ldots . . .$. Wilcox Formation.

Bayou Lenann Member ${ }^{4}$

Pendleton Formation

Ackerman Formation ${ }^{5}$

1 Of Wilbert (1953)

2 Yegua Member of Lisbon Formation as used by Mellen (1940). U.S. Geological Survey has restricted the term Yegua as a formation to Texas and restored the term Cockfield Formation for use in Mississippi, Louisiana, and Arkansas.

3 Of Stenzel (1953). Reklaw Formation of Stenzel in Texas overlies Carrizo Sand

and underlies Arp Member of Queen City Formation.
4 Of Murray and Thomas (1945). The term Pendleton is preoccupied.

5 Abandoned by U.S. Geological Survey. "Removal of beds designated as Holly Springs from Wilcox group left Ackerman formation as only unit *** formerly recognized by U.S. Geological Survey in Wilcox of Mississippi ***. It was decided ** to adopt Wilcox formation for all these beds in Mississippi." (MacNeil, 1946b).

as well as species that are similar or identical to species already described from the Tertiary of Europe. Identification of some species with previously described forms is readily established, but of others difficult, owing to inaccessibility of types, inadequate descriptions, or inadequate illustrations. The genera and species and the names used are those that seem most appropriate at the present time. Comments presented below are chiefly concerned with stratigraphic and geographic occurrence and distribution.

Maceopolipollenites tenuipolus (Anderson) Leffingwell, 1971

Plate 1, figures 1, 2

Pollen of Maceopolipollenites tenuipolus is absent from the Cretaceous, but is common in the Paleocene of the Mississippi embayment. It was found as sparse specimens in only the stratigraphically lowermost reference sample (Nanafalia Formation) in the Eocene Wilcox Group. Several other species of Maceopolipollenites are present as very sparse specimens in the Wilcox Group reference samples.

Affinity.-Juglandaceae.

Kyandopollenites anneratus Stover, 1966

Plate 1 , figures 3,4

Pollen of this monotypic, easily recognized genus Kyandopollenites was first reported by Stover (in Stover and others, 1966) from the lower Eocene Wilcox Group. I have observed sparse specimens in the Nanafalia, Wilcox, and Pendleton Formations. I have 


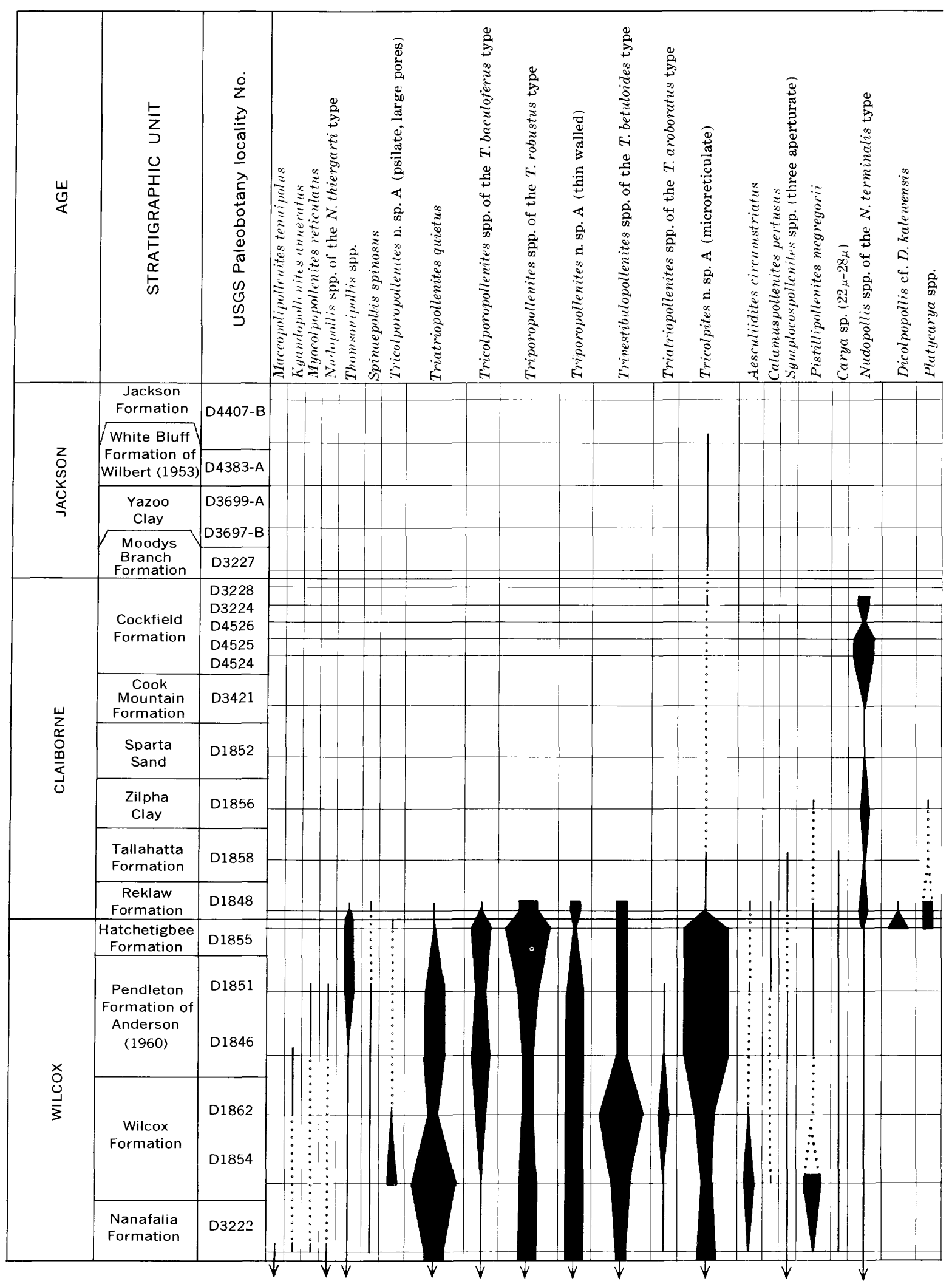

FIGURE 2.-Stratigraphic distributions and relative abundance of selected 


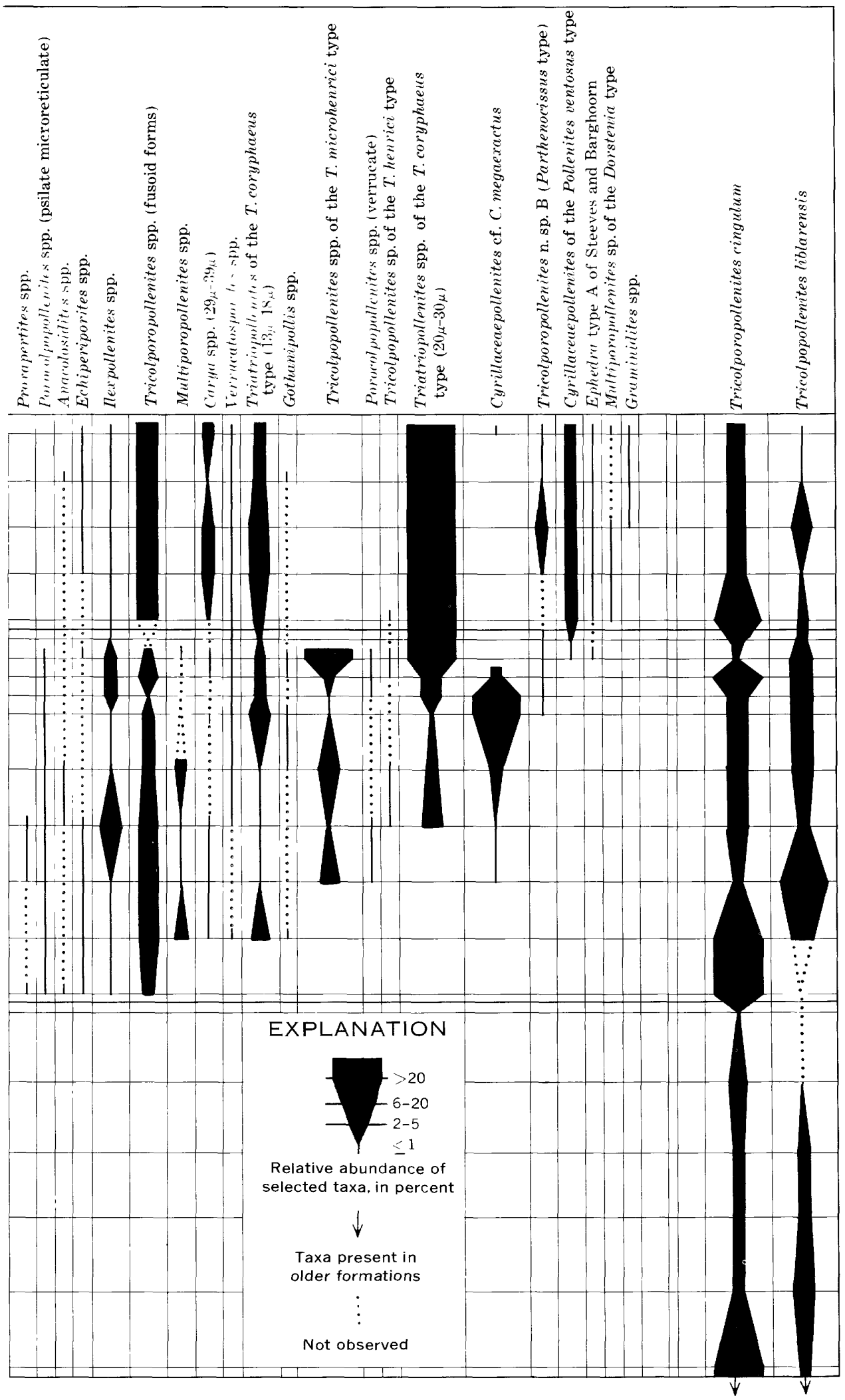

taxa from rocks of Wilcox, Claiborne, and Jackson ages. 
not found pollen of Kyandopollenites in the underlying Paleocene.

$$
\text { Affinity.-Not known. }
$$

Myocolpopollenites reticulatus Elsik, 1966

Plate 1, figure 5

The genus Myocolpopollenites was first described from specimens found in lignite of the Wilcox Group from Milam County, Tex. (Elsik, in Stover and others, 1966). Fairchild and Elsik (1969) reported it sparse and as limited to the Wilcox. I have found specimens of this genus and species in only three of our reference samples. They are sparse in the Nanafalia Formation sample (D3222), but much more common in the Pendleton Formation (samples D1846 and D1851), though present there in a frequency of at most 1 percent.

Affinity.-Illiciaceae?

\section{Nudopollis spp. of the $\mathbf{N}$. thiergarti type}

Plate 1, figures 6, 7

Two pollen types belonging to the genus Nudopollis, $N$. thiergarti and $N$. terminalis, are found in Eocene samples from the Mississippi embayment; these have distinct stratigraphic ranges. The Nudopollis thiergarti type is found frequently in Paleocene and older rocks and infrequently in lower Eocene rocks in which I have found it to be limited to the Nanafalia and Pendleton Formations. Fairchild and Elsik (1969) indicated that this pollen type became virtually extinct by the end of Wilcox time. The Nudopollis terminalis type is discussed on page B14.

Affinity.-Not known.

\section{Thomsonipollis spp. \\ Plate 1, figures 8,9}

The genus Thomsonipollis was first fully described by Krutzsch (1960a) from specimens found in the Wilcox Formation near Austin, Tex., and from the early Eocene of middle Europe. The genus, which is represented in our reference sample assemblages by at least two species, was found in some samples of the Paleocene and in all the Wilcox samples of the Eocene. Its frequency of occurrence increases in samples from the upper part of the Wilcox Group. This taxon is particularly useful as a stratigraphic marker inasmuch as it is virtually absent from samples younger than the Wilcox. I have found only one specimen in the Reklaw Formation sample and none in the samples from the overlying Claiborne and Jackson Groups.

Affinity.- -Not known.

\section{Spinaepollis spinosus (R. Pot.) Krutzsch, 1960b}

Plate 1, figures 10-12

L. E. Stover (in Stover and others, 1966) apparently had not seen the description of Spinaepollis when he described the new genus and species Sernapollenites duratus. The two descriptions are so similar that little doubt exists that they represent the same taxon. Stover's specimens are from the early Eocene of Milam County, Tex. Fairchild and Elsik (1969) said that this species "*** has been seen only in Wilcox sediments, more commonly in the upper Wilcox. The range of this species appears to be short in the Gulf Coast." The stratigraphic range of this species in Europe is from basal Paleocene through the Eocene. I found Spinaepollis spinosus to be limited to the Nanafalia, Wilcox, and Pendleton Formations and to the Reklaw Formation of the Claiborne Group in which I found only one specimen.

\section{Affinity.--Not known.}

Tricolporopollenites n. sp. A (psilate, large pores)

Plate 1, figures 13-17

Tricolporopollenites $\mathrm{n}$. sp. A is characterized by pollen with a relatively thick psilate exine, colpi that extend almost to the poles, and very large equatorial pores. It is best represented in sample D1854 (Wilcox Formation) in which many dicolporate grains also were found (pl. 1, figs. 16, 17). These dicolporate grains appear to be identical, except for the number of colpi, to the tricolporate specimens. This species was observed in the two Wilcox Formation samples and in the Hatchetigbee Formation sample. It has not been seen in any post-Wilcox samples.

Affinity.-Not known.

Triatriopollenites quietus (R. Pot.) Th. and Pf., 1953

Plate 1, figures 18-20

Pollen of Triatriopollenites quietus is characterized by regular, well-defined plicae extending from pore to pore over the poles. It is present in all Wilcox reference samples in a frequency of at least 5 percent, except for the uppermost sample (Hatchetigbee Formation). In sample D1854 Wilcox Formation it attains a frequency greater than 20 percent. It is present in the Reklaw Formation sample (lower part, Claiborne Group) but is virtually extinct above that level in the Eocene.

Affinity.--Probably Myricaceae (Th. and Pf., 1953).

Tricolporopollenites spp. of the $T$. baculoferus type

Plate 1, figures $21-26$

Several Tricolporopollenites species are probably included in this group, the T. baculoferus type, which is characterized by spherical to prolate pollen possessing pilate to clavate surface ornamentation. In some of the specimens, pores are extremely difficult to discern; in others the colporate characteristic is easily seen. Colpi are long (pl. 1, figs. 21-25) or short (pl. 1, fig. 26). Elsik (1968b) included both colpate and colporate forms in the species Tricolporopollenites baculoferus Pflug 1953. 
This group is present in the upper part of the Paleocene, but specimens become more common in the Wilcox. It is present in the Reklaw Formation (lower part, Claiborne Group) but is absent above this level. It has been found in all Wilcox samples in a frequency up to 10 percent.

Affinity.-Not known.

\section{Triporopollenites spp. of the T. robustus type}

Plate 2, figures 1,2

Pollen of this somewhat heterogeneous group, Triporopollenites spp. of the T. robustus type, is a principal element of all Wilcox samples. The pollen is triporate, rounded triangular to circular, and virtually psilate, and the ektexine is characteristically about twice as thick as the endexine. The pore areas may protrude in varying degree. This group is present in the Paleocene and also in the Reklaw Formation of the lower part of the Claiborne Group where it attains a frequency of 10 percent. Pollen of this group is virtually absent above this level:

Affinity.--Possibly Betulaceae (Th. and Pf. 1953).

Triporopollenites n. sp. A (thin walled)

Plate 2, figures 3, 4

The pollen of Triporopollenites $\mathrm{n}$. sp. A is triporate and smooth and has a rounded triangular to deltoid outline in polar view. The ektexine is less than $1_{\mu}$ thick and the endexine is even thinner and is characteristically broken up into more or less discrete granules. Pores usually do not protrude to a significant degree. This species has virtually the same stratigraphic range as the species of the Triporopollenites robustus type and attains a frequency of 7-14 percent in most Wilcox samples. It is present in the underlying Midway Group, as well as in samples from the Wilcox Group. It is present also in the lower part of the Reklaw Formation in the Claiborne Group but is absent from younger samples.

Affinity.-Not known.

\section{Trivestibulopollenites spp. of the T. betuloides type}

Plate 2, figures 5, 6

Pollen of Trivestibulopollenites spp. of the T. betuloides type appears to conform closest to that of Trivestibulopollenites betuloides Pflug 1953. The pores are always prominent and are provided with a vestibulum. This pollen type is present in the Paleocene and is fairly common in all Wilcox samples. It is also present in the Reklaw Formation sample but is absent from, or extremely sparse in, younger Eocene samples. Affinity.-Betulaceae.
Triatriopollenites spp. of the $T$. aroboratus type

Plate 2, figures 7, 8

Triatriopollenites spp. of the T. aroboratus type have comparatively large, thick-walled, subtriangular pollen grains. This type of pollen was referred to Triatriopollenites aroboratus Pflug 1953 by Elsik (1968b). It, however, does not fit well into the circumscriptions of any of Pflug's species of Triatriopollenites. This group in the Wilcox of the Mississippi embayment possesses the following characteristics: Outline, rounded triangular; ektexine, $1.5 \mu-2 \mu$ thick, psilate; endexine; equal in thickness to the ektexine or thinner, intragranulate; atrium, $5 \mu$ or more deep with granular endexine present; diameter, $35 \mu-50 \mu$. Although an atrium is present, its development is poor, making this taxon somewhat transitional between Triporopollenites and Triatriopollenites. This group of species is never abundant and is limited to the Nanafalia, Wilcox, and Pendleton Formations.

Affinity.-Not known.

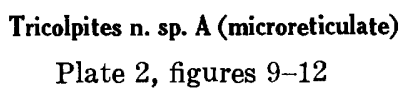

Elsik (1968b) placed specimens of Tricolpites $\mathrm{n}$. sp. A (microreticulate) in a species that has an extremely wide circumscription (Tricolpopollenites hians (Stanley) Elsik 1968). Pollen of this species will not be described here except for mention of the main characteristic. The colpi are without margos, and they possess prominent granules attached to the margins of the colpi which provide the apearance of torn colpi when seen in polar view. The irregular margins of the colpi can also be seen in equatorial view. Pollen of this species attains a frequency of 40 percent in the uppermost formation of the Wilcox Group, the Hatchetigbee Formation. It is present in very low frequency in the lowermost part of the Claiborne Group.

In the Wilcox and lower part of the Claiborne, specimens are small $(18 \mu-25 \mu)$. In the uppermost Cockfield and the Jackson, a larger form (pl. 2, figs. 11, 12) makes an appearance in low frequency. This variety (or species) is $30 \mu-38 \mu$ in diameter. The larger form has not been found in the Wilcox.

Affinity.-Possibly Platanaceae.

\section{Aesculiidites circumstriatus (Fairchild) Elsik, 1968b \\ Plate 2, figures 13-15}

Originally named Tricolpites circumstriatus by W. W. Fairchild (in Stover and others, 1966) from specimens found in lignite in the Rockdale Formation of the Wilcox Group, this taxon was renamed by Elsik. In our reference sample material, this species was observed as somewhat sparse specimeins in the Nanafalia, Wilcox, and Pendleton Formations. It was not observed in the 
Paleocene, but is present in the Reklaw Formation of the lower part of the Claiborne Group.

Affinity.-Hippocastanaceae?

\section{Calamuspollenites pertusus Elsik, 1966}

Plate 2, figures 16,17

Monosulcate pollen with characteristic scabrate (punctate) surface ornamentation has been reported by Elsik (in Stover and others 1966) as a rare species from the Wilcox Group. I have found it in the Wilcox, Pendleton, and Hatchetigbee Formations and in the Reklaw Formation (Claiborne Group). It has never appeared in any abundance.

\section{Affinity.-Palmae?, Magnoliaceae?}

Symplocospollenites spp. (three aperturate)

Plate 2, figures 23,24

Symplocospollenites is a form genus for pollen that have four to five pores and short colpi (Potonie, 1960a). Krutzsch (1960b, p. 317) claimed that it is inappropriate to bring together both rotundoid and vestibuloid forms in the same form genus. Hence, he considered the genus Porocolpopollenites (type species $P$. vestibuloformis Pf. 1953) appropriate for the three colporate vestibuloid forms and Symplocospollenites (type species S. rotundus R. Pot. 1960) for rotundoid forms. Most of the specimens found in the Wilcox Group are somewhat spherical but possess only three pores and short colpi. However, some specimens have the four pores and short colpi characteristic of many Symplocaceae pollen. Both the three- and the four-pored forms are here considered together as a group.

Pollen of this group has not been found in abundance in any sample. It has been recorded from all but one reference sample from the Wilcox Group and also from the Reklaw and Tallahatta Formations of the Claiborne Group. It is present but sparse in the Paleocene.

Affinity.-Symplocaceae.

Pistillipollenites mcgregorii Rouse, 1962

Plate 2, figures 21, 22

Pollen of Pistillipollenites mcgregorii is first observed in the Mississippi embayment region in the basal Wilcox Group, though elsewhere it has been reported from the Paleocene (Rouse and Srivastava, 1970). Pollen of this genus and species was found in all but one Wilcox sample as well as in the sample of the overlying Reklaw. A single specimen was found in the Zilpha Clay. Its presence in the Zilpha Clay may extend the range of Pistillipollenites into the mid-Claiborne; this one specimen, however, could have been redeposited. Further work in the Mississippi embayment undoubtedly will clarify the range of this species.

Affinity.- -Not known.
Carya sp. 22u-28u

Plate 2, figures 25, 26

Although never present in abundance, small pollen grains of this species of Carya are present in all Wilcox samples. Its range extends into the Reklaw and Tallahatta Formations of the Claiborne Group. It is absent from the Paleocene. Pollen of this genus provides an excellent marker for distinguishing Eocene from Paleocene in the Mississippi embayment region.

\section{Affinity.-Carya in Juglandaceae.}

\section{Nudopollis spp. of the $\mathrm{N}$. terminalis type}

Plate 2, figures 18-20

The distinguishing feature of Nudopollis spp. of the $N$. terminalis type (a prominent conical intrapunctate atrium) makes this group readily separable from the Nudopollis thiergarti type (p. B12). This group of species is present in pre-Eocene rocks and in the lower Eocene part of the Wilcox Group but becomes significantly more common in the Claiborne Group. It apparently becomes extinct in latest Claiborne time, though Fairchild and Elsik (1969, p. 85) reported seeing several specimens in the upper Eocene Jackson Group. This group is absent from the Jackson, as indicated by our reference samples.

Affinity.-Not known.

\section{Dicolpopollis cf. D. kalewensis R. Potonie, 1960b}

Plate 2, figures 27-29

Pollen of Dicolpopollis cf. D. kalewensis is present in appreciable numbers (10 percent) in the Hatchetigbee Formation of the Wilcox Group; this appearance is the first American record of the genus. It has previously been recorded from Europe (Kedves, 1968; Pflanzl, 1956), Burma (Potonie, 1960b), and Borneo (Muller, 1968). A very few specimens were noted in the Reklaw Formation sample. This easily recognized taxon with an apparently very short stratigraphic range potentially is a very useful fossil.

Affinity.-Amaryllidaceae?, Palmae?, Eucryphiaceae?

\section{Platycarya spp.}

Plate 2, figures 30-34

Pollen of Platycarya spp. a distinctive type (pl. 2, figs. 30,31 ) has a comparatively short stratigraphic range, according to its occurrence in the available reference material. It was recorded in the Hatchetigbee, Reklaw, and Zilpha Formations. It thus appears to be limited in this area to the transition between the Wilcox and Claiborne Groups. Krutzsch (1962, p. 277) erected the genus Plicatopollis for the larger pollen (pl. 2, figs. 32-34). Fairchild and Elsik (1969), however, included both the large and the small forms in the genus Platycarya. At least two species are definitely included 
here and probably two genera.

Affinity (small form).-Platycarya in Juglandaceae.

Affinity (large form).--Juglandaceae (Krutzsch, 1962).

\section{Proxapertites spp. \\ Plate 3, figures 1-4}

Our records of Proxapertites spp. show it to be present in the Reklaw, Zilpha, and Sparta Formations. Pollen of all species included in this genus is comparatively large. The two halves often are seen overlying one another. The size and the surface sculpture, however, permit identification when only one half is present. This pollen type apparently is limited to the lower part of the Claiborne Group.

Affinity.-Not known.

\section{Porocolpopollenites spp. (psilate-nicroreticulate)}

Plate 3, figures 5, 6

Pollen of psilate-microreticulate species of Porocolpopollenites was observed consistently in all but the uppermost samples from the Claiborne Group. Although consistently present, it never attains a frequency greater than 1 percent. Its stratigraphic range appears to be confined to the Claiborne Group.

Affinity.-Symplocaceae.

\section{Anacolosidites spp.}

Plate 3, figures 7-9

Pollen from the Claiborne and Jackson Groups assigned to the form genus Anacolosidites probably represents several species. This form genus is readily recognized by the presence of six nonequatorial pores. It has not been observed in any Wilcox Group samples.

Affinity.-Probably Olacaceae.

Echiperiporites spp.

Plate 3, figures 13, 14

The spiny polyporate pollen grains of Echiperiporites spp. occur consistently, though not in high frequency, in the lower part of the Claiborne Group and in the upper part of the Jackson Group. They have not been observed in any Wilcox Group sample. The disjunct stratigraphic occurrence of these species suggests the possibility that their distribution may be partly facies controlled.

Affinity.-Picrodendraceae?

\section{Ilexpollenites spp.}

Plate 3, figures $10-12$

In our reference samples from the Wilcox Group, representatives of Ilexpollenites were not observed. They are present in all Claiborne and Jackson Group samples, attaining a frequency of about 7 percent in the Sparta Sand sample. This group has been reported from the uppermost Wilcox by Fairchild and Elsik (1969).

Affinity.-Aquifoliaceae.

\section{Tricolporopollenites spp. (fusoid forms)}

Plate 3, figures 15-19

Pollen of the group Tricolporopollenites spp., represented by grains that have well-developed colpi and pores, is always seen in equatorial view. The surface sculpture is verrucate to microverrucate. Krutzsch (1957) and Kedves (1967) discussed these forms as "fusoide formen." The closest described form species is probably Tricolporopollenites pseudocingulum (R. Pot.) Th. and Pf. 1953. Fairchild and Elsik (1969) assigned specimens with the above characteristics to the modern genus Quercus. However, according to Erdtman (1952, p. 177), "The pollen grains in Fagaceae-except for Nothofagus only-belong to morphological types widely spread among dicotyledonous plants."

This group, represented by somewhat heterogeneous pollen types, is consistently present throughout the Claiborne and Jackson in frequencies, for the most part, greater than 5 percent. The presence of these forms in pollen assemblages is a good indication of a postWilcox age.

Affinity.-Anacardiaceae? and Fagaceae?

\section{Multiporopollenites spp. \\ Plate 3, figures 20-22}

Specimens of Multiporopollenites spp. a polyporate group, first appear in pollen assemblages in samples from the Tallahatta Formation (lower part of Claiborne Group). Members of this pollen group, however, are more common in samples from the middle Claiborne. Very few were found in the Cockfield Formation of the uppermost Claiborne Group, and none in samples from the Jackson Group.

Affinity.--Juglandaceae.

\section{Carya spp. $29 \mu-39 \mu$}

Plate 3, figures 25-27

Carya pollen in two size categories is present in the Eocene of the Mississippi embayment. The smaller forms, somewhat limited to the lower Eocene, have already been discussed (p.B14). The larger forms $\left(29_{\mu-}^{-}\right.$ $39 \mu$ ) first appear in the Tallahatta Formation and continue to be present throughout the remainder of the late Eocene. The stratigraphic distribution of the two forms is slightly overlapping - both forms being present in the Tallahatta Formation. The frequency of occurrence of the large species of Carya increases markedly in the Jackson Group samples.

Affinity.-Carya in Juglandaceae. 


\author{
Verrucatosporites spp. \\ Plate 3, figures 23, 24
}

The monolete fern spores of Verrucatosporites spp. have very coarse surface ornamentation, in particular those assigned to Verrucatosporites histiopteroides Krutzsch 1962, which first appear in the Tallahatta Formation. They are consistently present in all samples from the upper part of the Claiborne Group as well as from the Jackson Group. Fairchild and Elsik (1969, p. 83) said that this type of polypodiaceous spore is *** "restricted to Claiborne and younger sediments in the Gulf coast."

Affinity.-Polypodiaceae.

Triatriopollenites sp. of the T. coryphaeus type $(13 \mu-18 \mu)$

Plate 4, figures 1-3

Triatriopollenites sp. of the T. coryphaeus type $(13 \mu-$ $18 \mu$ ) includes small specimens of a group of triatriate pollen grains that first appear in the Claiborne Group and are present in abundance throughout the Jackson Group. Engelhardt (1964a) placed pollen of this type into Engelhardtioidites cf. E. microcoryphaeus, and Fairchild and Elsik (1969) assigned this type of pollen to the modern genus Engelhardtia. W. C. Elsik (oral commun., 1969) noted the presence of peltate leaf hairs morphologically similar to those of Engelhardtia in fossil pollen preparations from the Gulf Coast Tertiary. A modern pollen preparation in our laboratory of Engelhardtia chrysolepis Hance, from Kwansi, China, contains many peltate leaf hairs morphologically similar to those found in Claiborne and Jackson Group samples from the Mississippi embayment (pl. 4, figs. 36, 37). These hairs first appear in the Tallahatta Formation sample. Pollen grains of the Triatriopollenites coryphaeus type first appear in samples from the lower part of the Claiborne, and continue to be present in abundance in all samples from the Claiborne through the Jackson Groups. This pollen type can be separated into stratigraphically distinct units on the basis of size. The small members of this group first appear in the Tallahatta Formation and attain there a frequency of 16 percent. The larger members appear in younger formations. (See Triatriopollenites sp. of the T. coryphaeus type $(20 \mu-30 \mu)$.) The presence of this type of pollen in samples is very good evidence of a Claiborne or younger age.

Affinity.-Engelhardtia-Alfaroa? in Juglandaceae.

\section{Gothanipollis spp.}

Plate 4, figures 4, 5

Gothanipollis was first described by Krutzsch (1959) from the middle Eocene of Germany. Engelhardt (1964b) described a species of Gothanipollis from the upper part of the Cockfield Formation in Mississippi.
The stratigraphic range of this genus observed in the Mississippi embayment reference samples is from the Tallahatta Formation through the Jackson Group. The genus has not been observed in every Claiborne and Jackson reference sample. It is a comparatively infrequent taxon, never occurring in a frequency as great as 1 percent. In Europe, the range extends from the early Eocene to the late Oligocene.

Affinity.-Loranthaceae.

\section{Tricolpopollenites spp. of the T. microhenrici type} Plate 4, figures 6, 7

Pollen of the Tricolpopollenites spp. of the T. microhenrici type, a tricolpate prolate group of species, are commonly laterally compressed so that they present an equatorial view in the fossil state. This type is significant because it appears to be limited to the upper part of the Claiborne Group, and its frequency in this interval is often relatively high, attaining a maximum frequency of 25 percent.

\section{Affinity.-Fagaceae?}

Porocolpopollenites spp. (verrucate)

Plate 4, figures 8, 9

Verrucate pollen grains assignable to Porocolpopollenites, though sparse, are present in most of the samples from the upper part of the Claiborne Group. They have not been observed in samples from either the Wilcox or the Jackson Group.

Affinity.-Symplocaceae.

Tricolpopollenites spp. of the $T$. henrici type

Plate 4, figures 10, 11

Pollen representing Tricolpopollenites spp. of the $T$. henrici type possesses almost the same characteristics as pollen of the group Tricolpopollenites cf. T. microhenrici but are significantly larger $(35 \mu-45 \mu$ polar daimeter). The stratigraphic range of species assignable to this type encompasses the upper part of the Claiborne Group and the basal formation, the Moodys Branch Formation, of the Jackson Group.

$$
\text { Affinity.-Fagaceae? }
$$

Triatriopollenites sp. of the T. coryphaeus type $(20 \mu-30 \mu)$

Plate 4, figures 12,13

See Triatriopollenites ef. T. coryphaeus, $13 \mu-18 \mu$ group, p. B16. Pollen assignable to Triatriopollenites sp. of the $T$. coryphaeus type $(20 \mu 30 \mu)$ are larger than pollen of the $T$. coryphaeus $13 \mu-18 \mu$ group and are similar morphologically to pollen of EngelhardtiaAlfaroa. The larger specimens first appear in the Sparta Sand, then become dominant in the uppermost Cockfield Formation and the Jackson Group. This and the clearly related unit of smaller size represent a pronounced floral change in the Claiborne Group that 
continues through the Jackson. These size units combined attain a frequency of 16 percent in the middle Claiborne; then in the uppermost Cockfield samples and in the Jackson Group, attain a minimal frequency of 27 percent and a maximum of 75 percent.

Affinity.-Engelhardtia-Alfaroa in Juglandaceae.

\section{Cyrillaceaepollenites cf. C. megaexactus \\ Plate 4, figures 14-17}

Cyrillaceaepollenites cf. C. megaexactus, a species of pollen that appears in the upper part of the Claiborne Group, becomes a dominant element in some Cockfield Formation samples, then disappears from assemblages at the top of the Claiborne. A few specimens were observed in the upper part of the Jackson Group, sample D4407-B. These specimens suggest that the range of this species probably extends throughout the Jackson. It is a small species, easily overlooked when present in low frequency.

Affinity.-Cyrillaceae?

\section{Tricolporopollenites n. sp. B (Parthenocissus type)}

Plate 4, figures 18, 19

Pollen of Tricolporopollenites n. sp. B (Parthenocissus type) is characterized by deep colpi with a smooth area adjacent to the margins and a very heavy reticulum in the intercolpal areas. This pollen type first appears in the Cockfield Formation in the upper part of the Claiborne Group and ranges into the Jackson Group. It is similar in gross appearance to the pollen of the modern genus Parthenocissus.

Affinity.-Vitaceae?

Cyrillaceaepollenites of the Pollenites ventosus type

Plate 4, figures 20, 21

The pollen of Cyrillaceaepollenites of the Pollenites ventosus type is distinctly different from that of Cyrillaceaepollenites cf. $C$. megaexactus. This pollen type was first described and illustrated by a line drawing by Potonié (1931b). The drawing does not show the characteristics of the species and cannot be used to identify the fossil species. However, Potonié later (1934) redescribed the species Pollenites ventosus and provided a photograph. The photograph shows a grain which seems to have characteristics identical to those of the specimens shown in plate 4, figures 20, 21, and to the one figured by Englehardt (1964a) from the upper part of the Cockfield Formation of Mississippi. A similar grain was figured by Fairchild and Elsik (1969) and assigned to Pollenites pseudolaesius ${ }^{1}$ Potonie 1931a. The grain figured as $P$. pseudolaesus by Potonié in the 1931a publication is again a line drawing of doubtful usefulness in establishing identity. Traverse (1955) figured and described a pollen grain, as Clethra?,

\footnotetext{
1 Spelling as given by Fairchild and Elsik, 1969.
}

which is morphologically somewhat similar to the type under discussion.

Pollen of this type first appears in the upper part of the Cockfield (transition zone?) and is consistently present in all the overlying Jackson samples.

Affinity.- Not known.

Ephedra type A of Steeves and Barghoorn, 1959

Plate 4, figures 22, 23

Pollen belonging to the genus Ephedra is present in low frequency throughout the Eocene. Gray (1960) supplied a photograph of Ephedra type A (cf. E. nevadensis) pollen from the Gosport Sand, the uppermost formation of the Claiborne Group in Georgia and Alabama; and Fairchild and Elsik (1969) claimed that this type of pollen does not occur below the Claiborne. Pollen of Ephedra type A (distachya type) was observed in only one sample from the Claiborne Group (sample D3224 from the upper part of the Cockfield Formation) but was observed in all samples from the Jackson Group.

Affinity.-Ephedra in Gnetaceae.

Multiporopollenites sp. of the Dorstenia type

Plate 4, figures 29, 30

Pollen of the modern genus and species Dorstenia contrajerva in the Moraceae as figured by Erdtman (1952) is a very close approximation of the small multiporate pollen grains found in the Jackson Group of the Mississippi embayment region. These multiporate grains are distinctly smaller than those mentioned for Multiporopollenites spp. (pl. 3, figs. 20-22) and furthermore possess aspidate pores. Pollen of this species is a characteristic (though not abundant) element in all but one sample from the Jackson Group. It has not been observed in any samples older than Jackson.

Affinity.-Moraceae?

\section{Graminidites spp. \\ Plate 4, figures 34,35}

Monoporate pollen assignable without much question to the Gramineae was observed in the upper samples of the Jackson Group only. This type of pollen is easily recognized and therefore probably represents the approximate time of the appearance of grass in the Mississippi embayment region.

Affinity.-Gramineae.

Tricolporopollenites cingulum (R. Pot.) Th. and Pf. 1953

Plate 4, figures 24-28

Tricolporopollenites cingulum, a form genus and species, probably accommodates pollen from a heterogeneous group of plants, all of which produced tricolporate pollen characterized by small size, smooth to verrucate surface sculpture, and but few other distinguishing characteristics. Pollen of this species is 
present in all Eocene samples and is the dominant element in some. It attains a frequency of 52 percent and 45 percent, respectively, in the Reklaw and Tallahatta samples. Because it is a consistent element in all samples it is included here but separated from the other species on the stratigraphic chart.

Affinity.--Not known, probably various.

Tricolpopollenites liblarensis (Thoms) Th and Pf, 1953

Plate 4, figures 31-33

Tricolpopollenites liblarensis, which is similar to Tricolporopollenites cingulum in pollen characteristics of small size, smooth to verrucate surface sculpture, and few other distinguishing characteristics, is, however, tricolpate rather than tricolporate. It is included here because it is a consistent to abundant element of the Eocene control samples. It attains a maximum frequency of 35 percent in the Zilpha Clay sample.

Affinity.-Not known, probably various.

\section{CONCLUSIONS}

Criteria that serve to distinguish palynological assemblages in references samples from the Wilcox, Claiborne, and Jackson Groups have been observed in assemblages at many additional localities not discussed here. The floral changes observed are, in general, of regional extent. The criteria mentioned below and illustrated in figure 2 can be applied throughout the embayment area.

\section{THE WILCOX GROUP}

Palynological differentiation of the Wilcox Group from the upper part of the underlying Midway Group is accomplished by the recognition of several genera and species absent from the Midway but appearing first in the basal formations of the Wilcox. This palynological boundary is reinforced by the absence of some taxa in the Wilcox and younger rocks that are consistently present in the Midway.

Although appearing in low concentration in the basal Wilcox, Carya, a taxon readily recognizable by its pollen, makes its first appearance there. I have not seen this type of pollen in any sample from the Paleocene Porters Creek Clay, the equivalent Wills Point Formation, or Naheola Formation of the Midway Group, or in the Naborton Formation of the Wilcox Group. The palynological transition from the purported Paleocene to the purported Eocene is rather abrupt because a fairly easily recognizable palynological change is apparent. Several new species appear; these, however, usually represent only a fraction of 1 percent of the pollen in the total pollen counted. At the same level, many of the species present in purported Paleocene assemblages disappear. Pollen of Thomsonipollis was observed in all Wilcox Group samples, but only one specimen (in the Reklaw Formation) has been observed in any samples above the Hatchetigbee Formation (uppermost Wilcox). This genus accompanied by Carya serves to characterize the Wilcox Group. Other genera appearing for the first time in the basal Wilcox are Kyandopollenites, Spinaepollis, Myocolpopollenites, Aesculiidtes, and Pistillipollenites.

Triatriopollenites quietus, Tricolporopollenites of the T. baculoferus type, Triporopollenites of the T. robustus type, Trivestibulopollenites of the T. betuloides type, Triporopollenites n. sp. (thin walled), and Tricolpites $\mathrm{n}$. sp. A (microreticulate) are common to all Wilcox Group samples and occur in relatively high frequencies in most samples. All, however, persist into the basal Claiborne Group.

\section{THE CLAIBORNE GROUP}

The pollen assemblage from the Reklaw Formation is somewhat transitional, with species characteristic of the Wilcox Group persisting and species characteristic of the Claiborne Group appearing. The new taxa appearing first in the Reklaw Formation are Proxapertites, Anacolosidites, Ilexpollenites, Porocolpopollenites (psilate-microreticulate species), Echiperiporites, and Tricolporopollenites (fusoid forms). Those species characteristic of the Wilcox Group persist for the most part, in reduced frequency. Even though the Claiborne Group floras develop somewhat gradually, the Wilcox assemblages are sufficiently distinctive that little difficulty is experienced in distinguishing between the two.

The Tallahatta Formation sample provides the first specimens of a pollen group that becomes dominant in the Claiborne and persists through the JacksonTriatriopollenites of the T. coryphaeus type (probably Engelhardtia or Alfaroa). Additional Juglandaceous genera (Carya $29 \mu-39 \mu$ and Multiporopollenites) as well as Verrucatosporites and Gothanipollis appear first in the same sample.

The upper part of the Claiborne Group except for that represented by sample D3228 - the uppermost Cockfield Formation sample-is characterized by the presence of Nudopollis, Tricolporopollenites (species having fusoid pollen), Multiporopollenites, Tricolpopollenites of the T. microhenrici type, Cyrillaceaepollenites cf. C. megaexactus, and Triatriopollenites of the $T$. coryphaeus type.

\section{THE JACKSON GROUP}

The floral change from the Claiborne to the Jackson is distinctly transitional. The major frequency increase in the Triatriopollenites ef. T. coryphaeus $\left(20_{\mu}-30 \mu\right)$ type begins in the uppermost Cockfield Formation samples and continues throughout the Jackson. Pollen 
representing the larger new species of Tricolpites (Tricolpites n. sp. A, microreticulate), Ephedra (type A of Steeves and Barghoorn), Cyrillaceaepollenites of the Pollenites ventosus type, Tricolporopollenites $\mathrm{n}$. sp. B (Parthenocissus) type also appears first in the upper Cockfield Formation samples. These floral changes in the upper Cockfield Formation samples tend to support the hypothesis that the floral change from the Claiborne to the Jackson began prior to the deposition of the Moodys Branch Formation. (See section on "Claiborne-Jackson Stage Boundary".

Taxa that serve to characterize the nontransitional part of the Jackson Group include Multiporopollenites of the Dorstenia type and specimens assignable to the genus Nudopollis are absent from this interval. On strictly palynological grounds, I would place the Claiborne-Jackson boundary at the level of marked increase in frequency of the Triatriopollenites cf. T. coryphaeus type pollen, inasmuch as that level reflects a notable expansion of the Engelhardtia-Alfaroa forest and the disappearance of many of the characteristic older Eocene taxa.

\section{ANGIOSPERM FAMILIES REPRESENTED IN THE} EOCENE POLLEN FLORA

Ancillary information of some significance resulting from the present work is the recognition of Eocene pollen grains that are assignable to modern plant families. Climatic inferences concerning fossil floras depend upon the establishment of identity of the fossils with living counterparts whose ecological and climatic tolerances are known. Establishment of identity of Eocene plant microfossils with modern forms at the species level is extremely difficult. Identifications are more easily made at the generic level and still more easily made at the familial level.

Perhaps a more immediate application of knowledge concerning modern plant families represented in a fossil flora is in the study of the evolution and succession of floras in an area. The more families that can be recognized, the more complete the knowledge concerning the gross composition of the flora.

The only previously published direct or indirect references to angiosperm families represented by fossil pollen in the Eocene of the Mississippi embayment appear in papers by Gray (1960) in reference to the Claiborne pollen flora, by Elsik (1968a, b) in reference to the pollen flora in the Rockdale Formation of the Wilcox Group, and by Fairchild and Elsik (1969) in their paper on the characteristic palynomorphs of the Gulf Coast lower Tertiary.

A summary of the angiosperm families mentioned in the above papers and in the present work is given in table 4 .
Pollen grains representing several additional angiosperm families were observed but usually in very low frequency. Consequently these pollen types have not been included in the stratigraphic discussion.

TABLE 4. Angiosperm families represented by pollen reported from
the Mississippi embayment region

1 Observed but not mentioned in the stratigraphic discussion.

\section{REFERENCES CITED}

Andersen, H. V., 1960, Geology of Sabine Parish: Louisiana Geol. Survey Geol. Bull. 34, 164 p.

Berggren, W. A., 1965, Some problems of Paleocene-Lower Eocene planktonic foraminiferal correlations: Micropaleontology, v. 11 , no. 3 , p. 278-300.

Blanpied, B. W., and Hazzard, R. T., 1938, Correlation of Cockfield and Gosport formations, eastern Mississippi and western Alabama: Am. Assoc. Petroleum Geologists Bull., v. 22, no. 3, p. 309-314.

Cushing, E. M., Boswell, E. H., and Hosman, R. L., 1964, General geology of the Mississippi Embayment: U.S. Geol. Survey Prof. Paper 448-B, p. B1-B28.

DeVries, D. A., 1963, Jasper County mineral resources: Mississippi Geol. Econ. and Topog. Survey Bull. 95, p. 10-52.

Elsik, W. C., 1968a, Morphology and Taxonomy [pt] 1 of Palynology of a Paleocene Rockdale lignite, Milam County, Texas: Pollen et Spores, v. 10, no. 2, p. 263-314.

1968b, Morphology and Taxonomy (end), [pt] 2 of Palynology of a Paleocene Rockdale lignite, Milam County, Texas: Pollen et Spores, v. 10, no. 3, p. 599-664. 
Engelhardt, D. W., 1964a, Plant microfossils from the Eocene Cockfield Formation, Hinds County, Mississippi: Mississippi Geol. Econ. and Topog. Survey Bull. 104, p. 65-95.

$1964 \mathrm{~b}$, A new species of Gothanipollis Krutzsch from the Cockfield Formation (middle Eocene) of Mississippi: Pollen et Spores v. 6, no. 2, p. 597-600.

Erdtman, Gunnar, 1952, Pollen morphology and plant taxcnomy. Angiosperms (An introduction to palynology. I): Stockholm, Almqvist \& Wiksells; Chronica Botanica Co., Waltham, Mass., 539 p.

Fairchild, W. W., and Elsik, W. C., 1969, Characteristic palynomorphs of the lower Tertiary in the Gulf Coast: Palaeontographica, Abt. B., v. 128, p. 81-89.

Foster, V. M., 1940, Lauderdale County mineral resources: Mississippi Geol. Survey Bull. 41, 246 p.

Frederiksen, Norman Oliver, 1970, Stratigraphy and palynology of the Jackson Stage (Upper Eocene) and adjacent strata of Mississippi and western Alabama: Dissert. Abs. Internat., Sec. B, Science and Eng., v. 30 , no. 9, p. 4207 B.

Gray, Jane, 1960, Temperate Pollen genera in the Eocene (Claiborne) flora, Alabama: Science, v. 132 , no. 3430 , p. 808-810.

Holden, F. T., Hughes, U. B., Mellen, F. F., and Spooner, K. K., Compilers, 1948, The stratigraphy and paleontology of the Eocene, Oligocene and Miocene of Clarke and Wayne Counties, Mississippi [notes and plates], in Mississippi Geol. Soc. Guidebook, 6th Field Trip, 1948, p. 52-74 (reprinted from Shreveport Geol. Soc. Guidebook, 11th Ann. Field Trip, 1934).

Huff, W. J., 1970, The Jackson Eocene ostracoda of Mississippi: Mississippi Geol. Econ. and Topog. Survey Bull. 114, 289 p.

Jones, E. L., 1961a, Plant microfossils of the laminated sediments of the Lower Eocene Wilcox Group in south-central Arkansas: Oklahoma Univ., unpub. Ph. D. Dissert., 126 p., 9 pls.; Dissert. Abs., v. 22, p. 845.

$1961 \mathrm{~b}$, Environmental significance of palynomorphs from lower Eocene sediments of Arkansas: Science, v. 134, no. 3487, p. 1366.

-1962, Palynology of the Midway-Wilcox boundary in southcentral Arkansas: Gulf Coast Assoc. Geol. Soc. Trans., v. 12, p. 285-294.

Kedves, Miklos, 1967, Sur quelques problèmes de stratigraphie palynologique appliquée au Tertiare Inférieur en Europe: Pollen et Spores, v. 9, no. 2, p. 322-334.

_ 1968, Etudes Palynologiques des couches du Tertiare Inférieur de la région Parisienne. III. Pollens inaperturés à ballonnets polypliqués, monocolpés, disulqués, trichotomosulqués, et proxaperturés: Pollen et Spores, v. 10, no. 2, p. 315-334.

Krutzsch, W., 1957, Sporen-und Pollengruppen aus der Oberkreide und dem Tertiär Mitteleuropas und ihre stratigraphische Verteilung: Zeitschr. Angew. Geologie, v. 11-12, p. 509-548.

- 1959, Mikropalaontologische (Sporenpalaontologische) Untersuchungen in der Braunkohle des Geiseltales: Geologie, v. 21-22, p. 1-425.

1960a, Über Thomsonipollis magnificus (Th. \& Pf. 1953) n. fgen. n. comb. und Bemerkungen zur regionalen Verbreitung einiger Pollengruppen im älteren Paläogen: Freiburger Forschungshefte, no. C86, p. 54-65.

$1960 \mathrm{~b}$, Beitrag zur Sporenpaläontologie der präoberoligozänen kontinentalen und marinen Tertiärablagerungen Brandenburgs: Berichte der Geol. Gesell. DDR, v. 5, no. 4, p. 290-343.

- 1962, Stratigraphisch bzw. botanisch wichtige neue Sporenund Pollenformen aus dem deutschen Tertiär: Geologie, v. 11, no. 3 , p. $265-307$.
Leffingwell, H. A., 1971, Palynology of the Lance (Late Cretaceous) and Fort Union (Paleocene) Formations of the type Lance area, Wyoming-Symposium on palynology of the Late Cretaceous and Early Tertiary: Geol. Soc. America Spec. Paper 127, p. 1-64.

MacNeil, F. S., 1946a, Geologic map of the Tertiary formations of Alabama; U.S. Geol. Survey Oil and Gas Inv. Prelim. Map 45.

1946b, The Midway and Wilcox stratigraphy of Alabama and Mississippi: U.S. Geol. Survey Strategic Minerals Inv. Prelim. Rept. 3-195, 29 p.

McLaughlin, R. E., 1952, Plant microfossils from the Wilcox in northeast Louisiana: Tulane Univ., unpub. M.S. Thesis, 56 p., 24 pls.

1957, Plant microfossils from the Bruhn Lignite: Tennessee Univ., unpub. Ph. D. Dissert., 192 p., 7 pls.; Dissert. Abs., v. 17, p. 1881.

Mellen, F. F., 1940, Yazoo County mineral resources: Mississippi State Geol. Survey Bull. 39, p. 1-72.

Moore, W. H., 1965, Hinds County geology: Mississippi Geol. Econ. and Topog. Survey Bull. 105, p. 21-145.

Muller, Jan, 1968, Palynology of the Pedawan and Plateau Sandstone Formations (Cretaceous-Eocene) in Sarawak, Malaysia: Micropaleontology, v. 14, no. 1, p. 1-37.

Murray, G. E., 1955, Midway stage, Sabine stage, and Wilcox group [Gulf Coastal Plain]: Am. Assoc. Petroleum Geologists Bull., v. 39, no. 5, p. 671-696.

1961, Geology of the Atlantic and Gulf coastal province of North America: New York, Harper and Brothers, Publishers, $692 \mathrm{p}$.

Murray, G. E., Jr., and Thomas, E. P., 1945, Midway-Wilcox surface stratigraphy of Sabine uplift, Louisiana and Texas: Am. Assoc. Petroleum Geologists Bull., v. 29, no. 1, p. 45-70.

Murray, G. E., and Wilbert, L. J., Jr., 1950, Jacksonian stage [Atlantic and Gulf Coastal Plains]: Am. Assoc. Petroleum Geologists Bull., v. 34, no. 10, p. 1990-1997.

Pflanzl, G., 1956, Das Alter der Braunkohlen des Meissners, der Flöze 2 und 3 des Hirschberges und eines benachbarten Kohlenlagers bei Laudenbach: Notizblatt des Heissischen Landesamtes für Bodenforschung zu Weisbaden, v. 84, p. 232244, 1 table, 2 pls.

Potonié, Robert, 1931a, Pollenformen aus tertiären Braunkohlen: Jahrb. Preuss. Geol. L-A, v. 52, p. 1-7.

1931b, Zur Mikroskopie der Braunkohlen, IV. Tertiäre Sporen- und Blütenstaubformen: Zeitschr. Braunkohle, v. 30, no. 27 , p. $554-556$.

- 1934, Zur Mikrobotanik der Kohlen und ihrer Verwanten, II. Zur Mikrobotanik des eocänen Humodils des Geiseltals: Arbu. Inst. Paläobot. Petrographie Brennsteine, v. 4, p. 25125 .

1960, Synopsis der Gattungen der Sporae Dispersae, III. Teil-Nachträge Sporites, Fortsetzung Pollenites mit Generalregister zu Teil I-III: Geol. Jahrb. Beihefte, v. 39, 189 p.

- 1960b, Sporologie der eozänen Kohle von Kalewa in Burma: Senckenbergiana Lethaea, v. 41, no. 1-6, p. 451-481.

Priddy, R. R., 1960, Madison County geology: Mississippi Geol. Survey Bull. 88, 123 p.

1961, Geology study along Highway 80 from Alabama line to Jackson, Mississippi: Mississippi Geol. Survey Bull. 91, $62 \mathrm{p}$.

Rouse, G. E., 1962, Plant microfossils from the Burrard Formation of western British Columbia: Micropaleontology, v. 8, no. 2, p. $187-218$.

Rouse, G. E., and Srivastava, S. K., 1970, Detailed morphology, taxonomy and distribution of Pistillipollenites macgregorii: Canadian Jour. Botany, v. 48, no. 2, p. 287-292. 
Smith, F. E., 1959, Lower Tertiary and Upper Cretaceous of Brazos River Valley, Texas, in Houston Geol. Soc. and Gulf Coast Geol. Assoc., Soc. Econ. Paleontologists and Mineralogists Guidebook, Gulf Coast sec., Ann. Field Trip, 1959: 54 p.

Steeves, M. W., and Barghoorn, E. S., 1959, The Pollen of Ephedra: Jour. Arnold Arboretum, v. 40, no. 3, p. 221-255.

Stenzel, H. B., 1938, The geology of Leon County, Texas: Texas Univ. Bur. Econ. Geology Pub. 3818, 295 p.

1953, The geology of Henrys Chapel quadrangle, northeastern Cherokee County, Texas: Texas Univ. Bur. Econ. Geology Pub. 5305, 119 p.

Stover, L. E., Elsik, W. C., and Fairchild, W. W., 1966, New genera and species of early Tertiary palynomorphs from Gulf Coast: Kansas Univ., Paleont. Contr.-Paper 5, p. 1-11.

Thomson, P. W., and Pflug, H. D., 1953, Pollen und Sporen des Mitteleuropäischen Tertiärs: Palaeontograr hica, v. 94, sec. B, $138 \mathrm{p}$.

Traverse, A. F., Jr., 1955, Pollen analysis of the Brandon lignite of Vermont: U.S. Bur. Mines, Rept. Inv. 5151, p. 107.

Treadwell, R. C., 1954, Moodys Branch-Cockfield contact in Sabine Parish, Louisiana, and adjacent areas: Am. Assoc. Petroleum Geologists Bull., v. 38, no. 11, p. 2302-2323.
Tschudy, R. H., 1970, Two new pollen genera (Late Cretaceous and Paleocene) with possible affinity to the Illiciaceae: U.S. Geol. Survey Prof. Paper 643-F, 13 p.

Tschudy, R. H., and van Loenen, S. D., 1970, Illustrations of plant microfossils from the Yazoo Clay (Jackson Group, Upper Eocene) Mississippi: U.S. Geol. Survey Prof. Paper 643-E, 5 p., 1 fig., 5 pls.

Vestal, F. E., 1943, Choctaw County mineral resources: Mississippi State Geol. Survey Bull. 52, 156 p.

1954, Marshall County geology: Mississippi Geol. Survey Bull. 78, 193 p.

Warter, Janet Lee Kirchner, 1965, Palynology of a lignite of lower Eocene (Wilcox) age from Kemper County, Mississippi: Louisiana State Univ., unpub. Ph. D. Dissert., 213 p., 16 pls.; 1966, Dissert. Abs., v. 26, no. 8, p. 4199.

Wilbert, L. J., Jr., 1953, The Jacksonian Stage in southeastern Arkansas: Arkansas Resources and Develop. Comm., Div. Geology Bull. 19, 125 p.

White, C. D., and Thiessen, R., 1913, The origin of coal: U.S. Bur. Mines Bull. 38, 390 p. 



\section{N D E X}

[Italic page numbers indicate major references and descriptions]

A

Ackerman Formation

Acritarehs

Aesculiidites

circumstriatus _-_.

Alfaroa --_--_-

Amaryllidaceae -._-_-_-_-_-_-_._._. 14, 19

Anacardiaceae -...... 15, 19

Anacolosidites -_-_.

spp -

Angiosperm families represented in the Eocene pollen flora -.--- 19

Angiosperm specimens -..--.--_-_---

anneratus, Kyandopollenites _..._._. 9; pl. 1

Aquifoliaceae -----_-_-_-_-_-_-_-_ 15, 19

Archusa Marl Member

aroboratus, Triatriopollenites _-..--_ 18; pl. 2

baculoferus, Tricolporopollenites _- 4,12,18; pl. 1 Bashi Marl Member

Basic City Shale Member

Bayou Lenann Member of Pendleton

Formation - 4,9

Bells Landing Marl Member ......... 8

Betulaceae - - 13,19 betuloides, Trivestibulopollenites -- 13, 18; pl. 2 Bombacaeae

Bruhn lignite

Caesalpinaceae Calamuspollenites pertusus -

Cane River Formation - 7

Carrizo Sand -

Carya -_._._. 14, 15, 18

sp. $22 \mu-28 \mu$

spp. $29 \mu-39 \mu$ _-_-_-_------- 15, 18; pl. 3

Chenopodiaceae-Amaranthaceae -------- 19

chrysolepis, Engelhardtia -...-.....-- 16

cingulum, Tricolporopollenites _-.- 17, 18; pl. 4

circumstriatus, Aesculiidites _._._.... 13; pl. 2

Tricolpites 13

Claiborne Group _....... 1, 3, 7, 8, 12,13, 14, 18

Claiborne-Jackson Stage boundary -.-.- 8

Clayton Formation -----_-_-_------ 7

Clethra

Cockfield Formation of

Mississippi _-.._-_ 2, 6, 7, 8, 9, 13

Cocoa Sand Member - 7

Combretaceae -

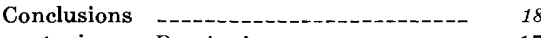

contrajerva, Dorstenia _-_-_____._. 17

Cook Mountain Formation _-_-_-_-_-_ 6, 7, 9

coryphaeus, Triatriopollenites -_._-_ 18, 19

coryphaeus $13 \mu-18 \mu$, Triatriopollenites _- $16 ; \mathrm{pl}, 4$ coryphaeus, $20 \mu-30 \mu$,

Triatriopollenites ---- 16, 18; pl. 4

Creola Member -..-_-_-_-_-_......-- 9

Cyrillaceae -_-_-_- 17, 19

Cyrillaceaepollenites megaexactus - 17, 18; pl. 4 of the Pollenites ventosus

type --_-_-_-_-- 17,$19 ; \mathrm{pl} .4$
D Page

Dicolpopollis kalewensis _-_._._-_._-_ 14; pl. 2

Dinoflagellates -.- 3

Dolet Hills Formation _-_._-_-_-_-_ 7

Dorstenia --_..- 17, 19; pl. 4 contrajerva _... 17

duratus, Sernapollenites _-_-_-_-_-- 12

$\mathbf{E}$

Echiperiporites --_-_-_-_-_-_-_...-- 18 spp Engelhardtia chrysolepis - 16 Engelhardtia-Alfaroa Engelhardtioidites microcoryphaeus ---- 16 Eocene Series Ephedra -_-_-_._. 17, 19 type A (distachya type) -..... 17 (nevadensis) of Steeves and Barghoorn _. $1 \%, 19 ;$ pl. 4 Eucryphiaceae

Fagaceae -

Fearn Springs Member

Flour Island Formation

Fort Pillow Sand

Fossil palynomorph localities -_-_-_-_-_-

G

Gnetaceae -

Gordon Creek Shale Member _....... 7

Gosport Sand of the Claiborne Group -- 2

Gothanipollis _-

spp

Gramineae -_...-_-_- 4, 17, 19

Graminidites spp

Grampion Hills Member _....-_-_-_-- 8

Gravel Creek Sand Member --_-_-_- 8

Greggs Landing Marl Member -...- 8

Hamamelidaceae - Hatchetigbee Formation _-.--- 4, 8, 9, 12, 13, 14 henrici, Tricolpopollenites _-_-_-_---1 16; pl. 4 hians, Tricolpopollenites -_. 13 Hippocastanaceae -...-_-_-_-_-_-_-_ 14, 19

histiopteroides, Verrucatosporites -..--- 16

Holly Springs Sand Member

Ilexpollenites -_pp Illiciaceae - -

\section{$\mathbf{J}$}

Jackson Formation $6,7,9,13$ Jackson Group Jackson Stage of Mississippi and Alabama
Jacksonian Stage

Page Juglandaceae

\section{$\mathrm{K}$}

kalewensis, Dicolpopollis _...-_-__._ 14; pl. 2 Kyandopollenites -_._-_._-_._._-_ 4, 9, 12, 18 anneratus _-_-_._-_._-_-_-_.-. 9 ; pl. 1

L

liblarensis, Tricolpopollenites _-_._-_ 18; pl. 4 Loranthaceae _._-_-_-_-_-_-_-_-__-__-_ 16,19

\section{M}

Maceopolipollenites tenuipolus - 4,$9 ; \mathrm{pl} .1$ megregorii, Pistillipollenites _-_-__- 14; pl. 2 Magnoliaceae _-_..- 14, 19

Marquez Shale Member _..._-_._-_ 4, 9 megaexactus, Cyrillaceaepollenites $-17,18$; pl. 4 Memphis Sand

Meridian Sand Member _._...-_-_ 7,8 Methods -...-...-_. 3 microcoryphaeus, Engelhardtioidites --- 16 microhenrici, Tricolpopollenites _-_ 16, 18; pl. 4 Middle member

Midway Group -

Midway-Sabine Stage Boundary _-_._- 8

Midway Stage -

Moodys Branch Formation _... 6, 7, 8, 9

Moraceae -_. 17, 19

multilirata, Ostrya -

Multiporopollenites --_-_-_-_-_-_-_ 18, 19 sp. of the Dorstenia type --- 17,$19 ;$ pl. 4 spp -----_-_-_-_-_-_-_-_-_- $15 ; \mathrm{pl} .3$

Myocolpopollenites _.-_-_-_-_-_-_-_-_ 12, 18 reticulatus _-_._. $12 ;$ pl. 1

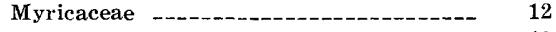

Myrtaceae _._._._- 19

$\mathbf{N}$

Naborton Formation -..-. 7

Naheola Formation -

Nanafalia Formation

Neshoba Sand Member _-_-_-_-_-_- 7

nevadensis, Ephedra

Normapolles Group -

North Creek Member --_-_-_-_---- 7

Nothofagus -----

Nudopollis _........ 12, 18, 19

terminalis _............ 12,$14 ;$ pl. 2

thiergarti _-_-_-_-_-_-_-_-- 12, 14; pl. 1

spp --1--_-_-_-_- 14

Nyssaceae - 19

o

Olacaceae - -

Old Breastworks Formation --_-_---- 7

Onagraceae -.--_- 19

Ostrea multilirata zone --_-_-_-_-_- 4

$\begin{array}{rr}\text { thirsae } & 8 \\ \text { Ostrya multilirata } & 8\end{array}$ 
Pachuta Marl Member

Paleocene Series

Palmae

Palynological work, previous --_-_-_-_-

Pandanaceae - -

Papilionaceae - 19

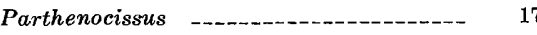

Pendleton Formation _-....-- 2, 4, 9, 12, 13, 14

pertusus, Calamuspollenites --14; pl.

Picrodendraceae -

Pistillipollenites -_-_-_-_._-_ 14, 18

mcgregorii -

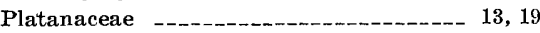

Platycarya -...-_-_-_._- 14, 15 spp -

Plicatopollis _-_._- 14

Pollenites pseudolaesius - 17

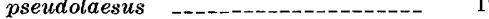
ventosus -_-_-_-_-_-_-_-_-_- 17, 19

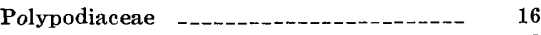

Porocolpopollenites -_-_-_-_-_-_ 14, 15, 16, 18

vestibuloformis _....- 14

spp -

Porters Creek Clay

Potterchito Sand Member

Preparing slides -

Processing samples

Proxapertite

pseudocingulum, Tricolporopollenites --- 15

pseudolaesius, Pollenites _-_._..._...- 17

pseudolaesus, Pollenites

Q

Qualitative counts

Quantitative counts

Queen City Sand

Quercus
quietus, Triatriopollenites

$\mathbf{R}$

Reklaw Formation _-_._-_._ 2, 7, 8, 9, 12, 13, 14 Restionaceae 19 reticulatus, Myocolpopollenites -.- 12; pl. 1
Page

robustus, Triporopollenites _-_._-_ 13, 18; pl. 2 Rockdale Formation of Wilcox Group _- 2, 13 rotundus, Symplocospollenites _-..--..- 14 Ruppiaceae

Sabine-Claiborne Stage boundary -.---Sabine Stage

Saline Formation of Wilcox Group

Sapindacea

Sapotaceae

Sernapollenites duratus

Shubuta Member

Sparta Sand

Spinaepollis

spinosus

pinosus, Spinaepollis

Stratigraphic ranges of selected taxa or groups of taxa

Stratigraphy -

Stratigraphy -

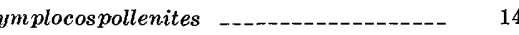

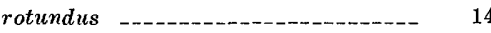

spp _-

Tallahatta Formation - $4,7,8,9,14$ tenuipolus, Maceopolipollenites _... 4, 9; pl. 1 terminalis, Nudopollis _..._._._. 12, 14; pl. 2 thiergarti, Nudopollis _-_._-_._. 12, 14; pl. 1

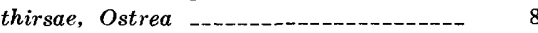
Thomsonipollis _._-_._-_-_-_-_ 2, 3, 12, 18 spp _-_._-

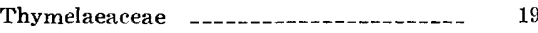

Tiliaceae --.---_-_- 19

Triatriopollenites _- 13,18

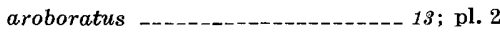
eoryphaeus _..-_. 18, 19

$13 \mu-18 \mu$

$20 \mu-30 \mu$ quietus _-_. sp Tricolpites circumstriatus _-_-_...- 13 n. sp. A
Tricolpopollenites -_henrici hians _-_...- 13

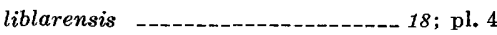
microhenrici _..._-_._-_-_.- 16, 18; pl. 4 spp -

Tricolporopollenites _-_-_-_-_-_._._. 12, 18 baculoferus -_-_-_-_._.- 4,12, 18; pl. 1 cingulum _-_._-__-_-_-_-_ 17, 18; pl. 4 pseudocingulum _-_._. 15 n. sp. A _-

n. sp. B (Parthenocissus type) --- 17, 19; pl. 4

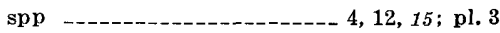

Triporopollenites _-_.-_- 13, 18 robustus _-_-_._-_-_-_-_-_-_ 13,18; pl. 2 n. sp. A -

Trivestibulopollenites betuloides _- 13, 18; pl. 2 Tuscahoma Formation of Wilcox Group _- 2,8

\section{U, V}

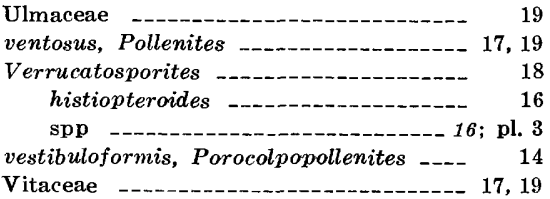

\section{W}

Weches Greensand White Bluff Formation Wilcox Formation _._............ 4, 7, 8, 14 Wilcox Group _._._._._._. 1, 3, 7, 8, 12, 13, 18 Wills Point Formation Winona Sand _............. 7

\section{$\mathbf{Y}, \mathbf{Z}$}

Yazoo Clay _Yegua Member, Lisbon Formation --_ 9

Zilpha Clay --_-_._._. 6, 7, 9, 14 Zilpha Formation - 


\section{PLATES 1-4}

[Contact photographs of the plates in this report are available, at cost, from U.S.

Geological Survey Library, Federal Center, Denver, Colorado 80225.] 


\section{PLATE 1}

[Magnification $\times 1,000]$

Figures 1,2. Maceopolipollenites tenuipolus (p. B9).

1. D3222, slide 3, coordinates $103.2 \times 15.0$, diameter $17 \mu$, Nanafalia Formation.

2. D3222, slide 1 , coordinates $108.4 \times 20.5$, diameter $19 \mu$, Nanafalia Formation.

3, 4. Kyandopollenites anneratus (p. B9).

3. D1846, slide 1, coordinates $102.4 \times 11.8$, diameter $55 \mu$, Pendleton Formation of Andersen (1960), low focus.

4. Same specimen, high focus.

5. Myocolpopollenites reticulatus (p. B12).

D1846, slide 9, coordinates $80.7 \times 20.7,53 \times 44 \mu$, Pendleton Formation of Andersen (1960).

6, 7. Nudopollis spp. of the N. thiergarti type (p. B12).

6. D3222, slide 2, coordinates $108.2 \times 6.4$, diameter $29 \mu$, Nanafalia Formation.

7. D3222, slide 1, coordinates $107.4 \times 15.2$, diameter $27 \mu$, Nanafalia Formation.

8, 9. Thomsonipollis spp. (p. B12).

8. D1855, slide 5 , coordinates $107.1 \times 18.9$, diameter $29 \mu$, Hatchetigbee Formation.

9. D1854, slide 3, coordinates $93.2 \times 18.0,30 \times 33 \mu$, Wilcox Formation (formerly Ackerman Formation).

10-12. Spinaepollis spinosus (p. B12).

10. D3222, slide 1, coordinates $81.6 \times 19.0$, diameter $29 \mu$, Nanafalia Formation. Apertures obscure in this species.

11. D1848, slide 1 , coordinates $107.7 \times 2.9$, diameter $27 \mu$, Reklaw Formation.

12. D1846, slide 4, coordinates $86.1 \times 12.8$, diameter $27 \mu$, Pendleton Formation of Andersen (1960). Note rosette arrangement of basal part of spines.

13-17. Tricolporopollenites n. sp. A (psilate, large pores) (p. B12).

13. D1854, slide 3, coordinates $107.7 \times 11.3,37 \times 29 \mu$, Wilcox Formation (formerly Ackerman Formation).

14. D1854, slide 3, coordinates $107.7 \times 14.7,39 \times 29 \mu$, Wilcox Formation (formerly Ackerman Formation).

15. D1854, slide 3, coordinates $87.0 \times 13.5,35 \times 32 \mu$, Wilcox Formation (formerly Ackerman Formation).

16. D1854, slide 3, coordinates $106.9 \times 11.8,32 \times 29 \mu$, Wilcox Formation (formerly Ackerman Formation). This specimen and figure 17 represent dicolporate variations of the same species shown in figures 13-15.

17. D1854, slide 2, coordinates $109.8 \times 19.9,30 \times 27 \mu$, Wilcox Formation (formerly Ackerman Formation).

18-20. Triatriopollenites quietus (p. B12).

18. D3222, slide 1 , coordinates $78.8 \times 17.3$, diameter $19 \mu$, Nanafalia Formation.

19. D3222, slide 1 , coordinates $88.7 \times 15.9$, diameter $19 \mu$, Nanafalia Formation.

20. D1862, slide 5, coordinates $114.6 \times 18.5$, diameter $20 \mu$, Wilcox Formation (formerly Ackerman Formation).

21-26. Tricolporopollenites spp. of the T. baculoferus type (p. B12).

21. D1862, slide 6, coordinates $86.9 \times 4.5$, diameter $40 \mu$, Wilcox Formation (formerly Ackerman Formation). view of specimen with long colpi.

22. D1846, slide 5, coordinates $87.2 \times 10.8,47 \times 40 \mu$, Pendleton Formation of Andersen (1960). Note well-developed pores and colpi here and in figure 23.

23. D1862, slide 6, coordinates $81.6 \times 21.6,39 \times 31 \mu$, Wilcox Formation (formerly Ackerman Formation).

24. D1855, slide 6, coordinates $98.9 \times 4.9,34 \times 30 \mu$, Hatchetigbee Formation. Colporate condition poorly developed or absent in this specimen and in figure 25 .

25. D3222, slide 1, coordinates $79.6 \times 18.5,37 \times 32 \mu$, Nanafalia Formation.

26. D1862, slide 1, coordinates $105.8 \times 12.5$, diameter $35 \mu$, Wilcox Formation (formerly Ackerman Formation). Not the short colpi in this specimen in contrast to the long colpi displayed on figure 21. 

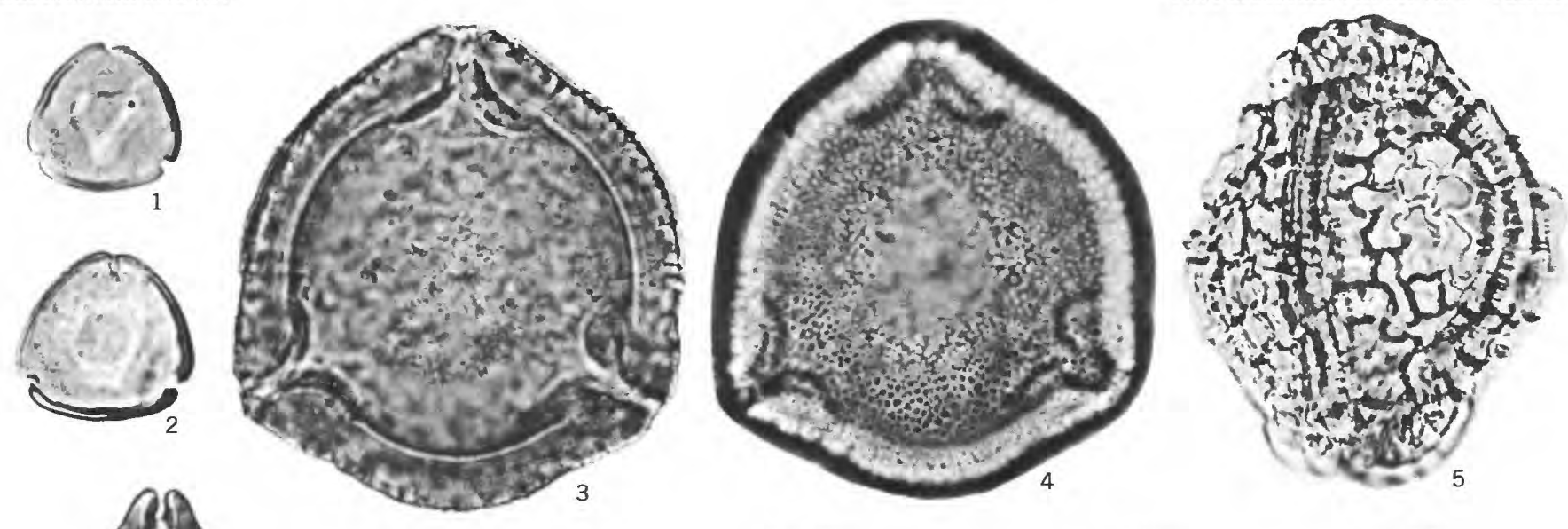

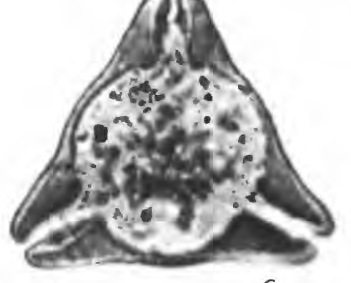

6
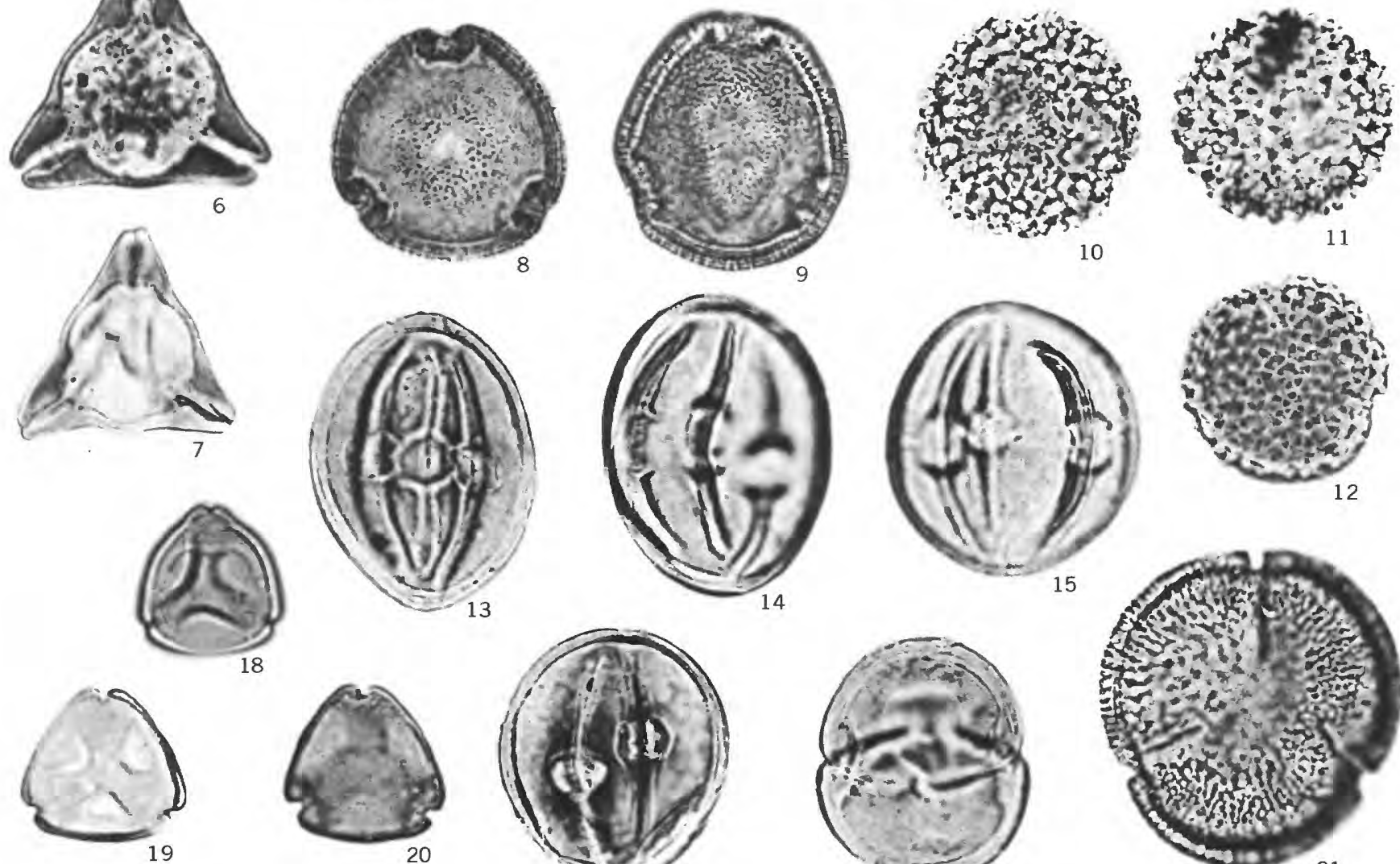

10
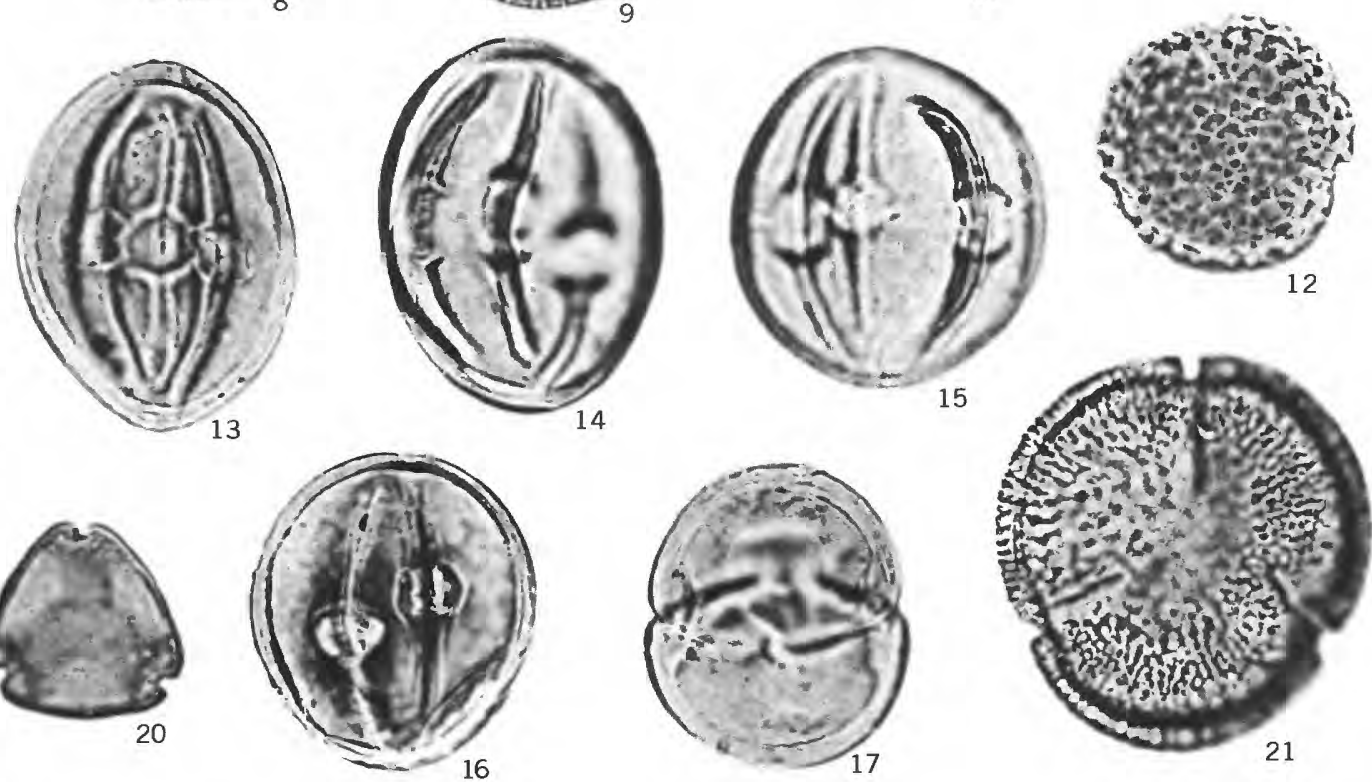
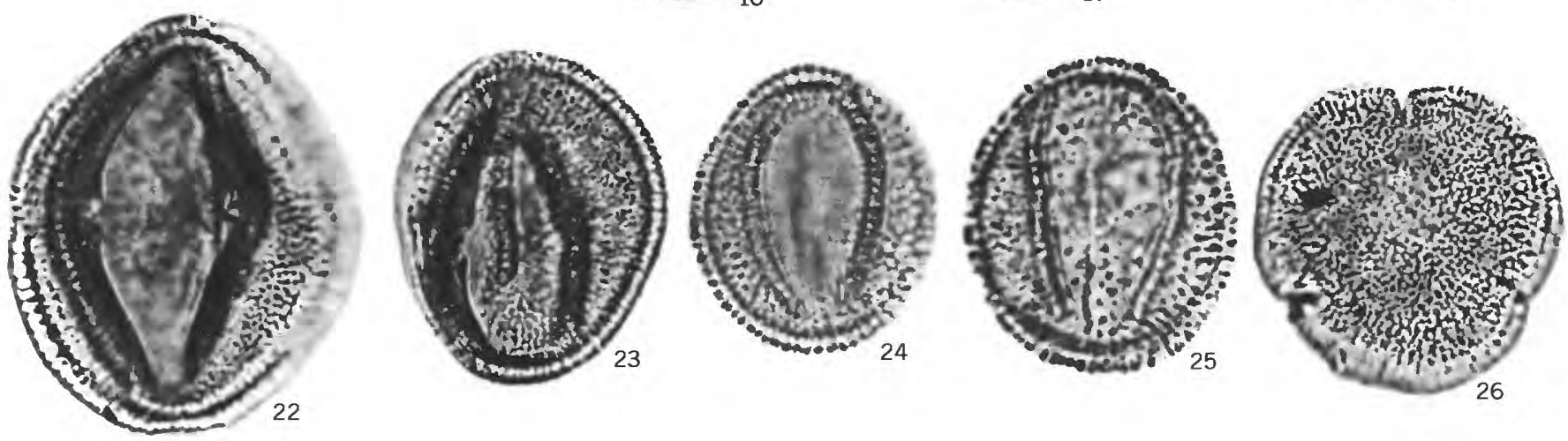

POLLEN FROM WILCOX GROUP 


\section{PLATE 2}

[Magnification $\times 1,000$ ]

Figures 1,2. Triporopollenites spp. of the T. robustus type (p. B13).

1. D3222, slide 1, coordinates $76.5 \times 5.9$, diameter $29 \mu$, Nanafalia Formation. High focus.

2. Same specimen, low focus.

3,4. Triporopollenites n. sp. A (thin walled) (p. B13).

3. D3222, slide 1, coordinates $98.5 \times 14.0$, diameter $34 \mu$, Nanafalia Formation. Almost circular form.

4. D1846, slide 5, coordinates $93.0 \times 6.3$, diameter $40 \mu$, Pendleton Formation of Andersen (1960). Deltoid form with larger pores.

5,6. Trivestibulopollenites spp. of the T. betuloides type (p. B13).

5. D1862, slide 6, coordinates $107.3 \times 7.4$, diameter $27 \mu$, Wilcox Formation (formerly Ackerman Formation).

6. D1862, slide 6, coordinates $82.1 \times 12.7,29 \times 24 \mu$, Wilcox Formation (formerly Ackerman Formation). Oblique equatorial view.

7,8. Triatriopollenites spp. of the T. aroboratus type (p. B13).

7. D3222, slide 3, coordinates $107.8 \times 11.0$, diameter $45 \mu$, Nanafalia Formation. Note granulate endexine in area of atria.

8. D3222, slide 2, coordinates $108.3 \times 17.0$, diameter $38 \mu$, Nanafalia Formation.

9-12. Tricolpites n. sp. A (microreticulate) (p. B13).

9. D3222, slide 2, coordinates $109.6 \times 20.5$, diameter $19 \mu$, Nanafalia Formation.

10. D1855, slide 6 , coordinates $82.0 \times 20.7$, diameter $23 \mu$, Hatchetigbee Formation.

11. D3699-A, slide 3, coordinates $101.9 \times 8.9$, diameter $36 \mu$, Yazoo Clay.

12. D3699-A, slide 4 , coordinates $92.1 \times 14.2$, diameter $38 \mu$, Yazoo Clay.

13-15. Aesculiidites circumstriatus (p. B13).

13. D1854, slide 4, coordinates $107.9 \times 4.2,22 \times 18 \mu$, Wilcox Formation (formerly Ackerman Formation). Colporate condition clearly displayed.

14. D1851, slide 2, coordinates $99.7 \times 11.7,23 \times 19 \mu$, Pendleton Formation of Andersen (1960).

15. D1851, slide 1, coordinates $100.1 \times 10.0,25 \times 18 \mu$, Pendleton Formation of Andersen (1960). Pores obscure in this specimen and in figure 14 .

16,17. Calamuspollenites pertusus (p. B14).

16. D1854, slide 3 , coordinates $98.5 \times 12.4,35 \times 23 \mu$, Wilcox Formation (formerly Ackerman Formation).

17. D1854, slide 3, coordinates $95.9 \times 18.3,31 \times 24 \mu$, Wilcox Formation (formerly Ackerman Formation).

18-20. Nudopollis spp. of the N. terminalis type (p. B14).

18. D1862, slide 3 , coordinates $100.0 \times 3.1$, diameter $35 \mu$, Wilcox Formation (formerly Ackerman Formation).

19. D1848, slide 2, coordinates $92.8 \times 8.8$, diameter $24 \mu$, Reklaw Formation.

20. D3222, slide 1 , coordinates $79.2 \times 20.9$, diameter $30 \mu$, Nanafalia Formation.

21,22. Pistillipollenites megregorii (p. B14).

21. D1854, slide 4, coordinates $101.7 \times 15.4$, diameter $22 \mu$, Wilcox Formation (formerly Ackerman Formation).

22. D1854, slide 4, coordinates $79.7 \times 10.5$, diameter $26 \mu$, Wilcox Formation (formerly Ackerman Formation).

23,24 . Symplocospollenites spp. (three aperturate) (p. B14).

23. D1848, slide 1 , coordinates $110.8 \times 10.4$, diameter $22 \mu$, Reklaw Formation.

24. D1862, slide 7, coordinates $113.0 \times 21.5$, diameter $29 \mu$, Wilcox Formation (formerly Ackerman Formation).

25, 26. Carya sp. $22 \mu-28 \mu$ (p. B14).

25. D1848, slide 2 , coordinates $101.5 \times 15.9$, diameter $28 \mu$, Reklaw Formation.

26. D3222, slide 1 , coordinates $99.0 \times 15.0$, diameter $28 \mu$, Nanafalia Formation.

27-29. Dicolpopollis cf. D. kalewensis (p. B14).

27. D1855, slide 6, coordinates $94.1 \times 13.5,28 \times 21 \mu$, Hatchetigbee Formation.

28. D1855, slide 6, coordinates $98.0 \times 3.5,27 \times 22 \mu$, Hatchetigbee Formation.

29. D1855, slide 6, coordinates $80.0 \times 15.1,28 \times 20 \mu$, Hatchetigbee Formation.

30-34. Platycarya spp. (p. B14).

30. D1855, slide 5 , coordinates $91.4 \times 21.2$, diameter $19 \mu$, Hatchetigbee Formation.

31. D1855, slide 6 , coordinates $82.0 \times 20.7$, diameter $20 \mu$, Hatchetigbee Formation.

32. D1848, slide 2, coordinates $109.5 \times 12.9$, diameter $29 \mu$, Reklaw Formation. This and the succeeding two specimens can be assigned to the form genus Plicatopollis.

33. D1848, slide 2, coordinates $107.3 \times 13.9$, diameter $27 \mu$, Reklaw Formation.

34. D1848, slide 1 , coordinates $113.3 \times 6.4$, diameter $28 \mu$, Reklaw Formation. 

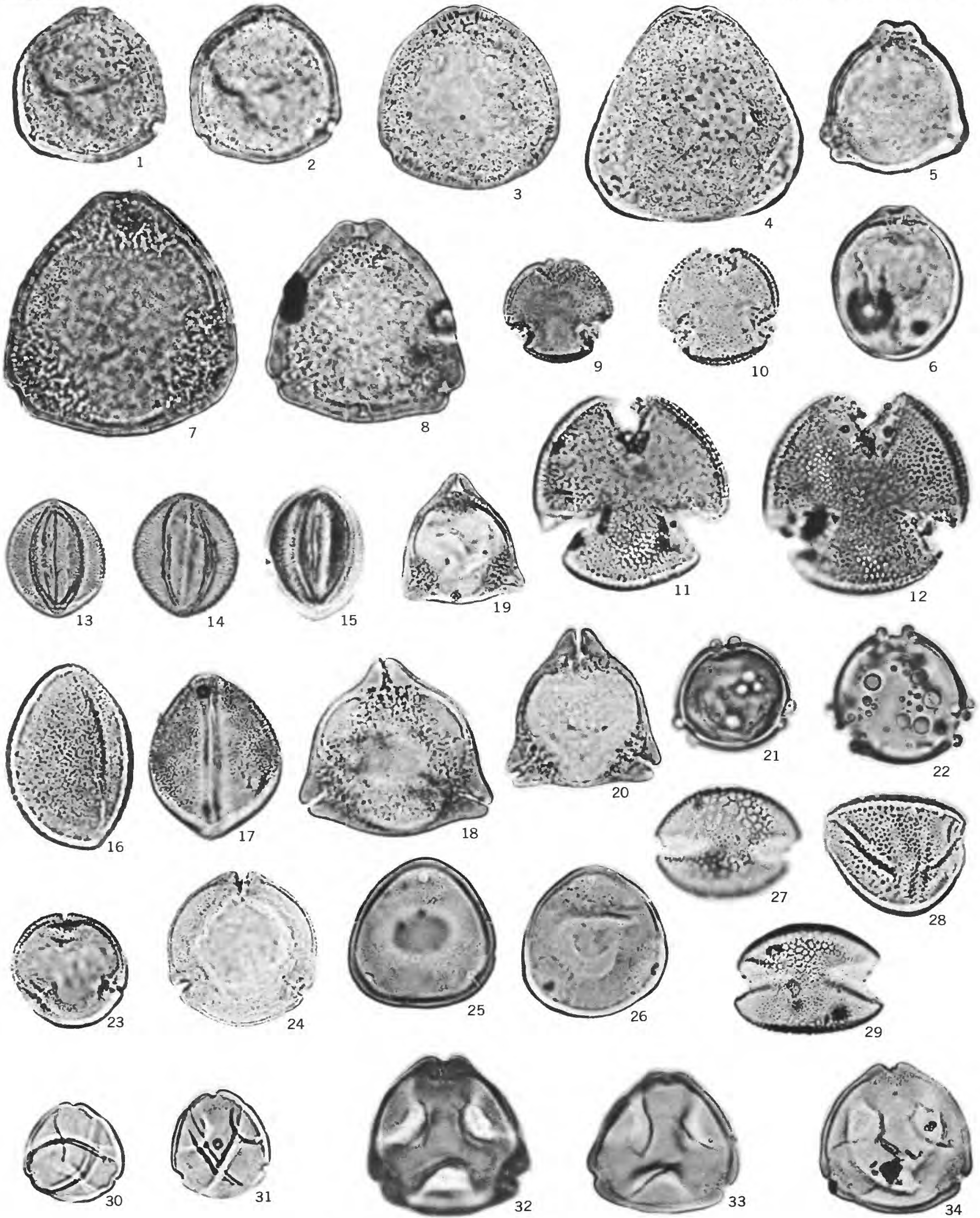

POLLEN FROM WILCOX AND CLAIBORNE GROUPS 


\section{PLATE 3}

[Magnification $\times 1,000$ ]

Figures 1-4. Proxapertites spp. (p. B15).

1. D1848, slide 2 , coordinates $82.4 \times 18.6,46 \times 38 \mu$, Reklaw Formation. This specimen as well as that represented by figure 4 are isolated halves. The complete fossil is represented by figures 2 and 3 .

2. D1848, slide 2, coordinates $109.2 \times 15.7,48 \times 40 \mu$, Reklaw Formation.

3. D1848, slide 3, coordinates $109.3 \times 17.7,45 \times 38 \mu$, Reklaw Formation.

4. D1848, slide 2, coordinates $84.0 \times 16.6,48 \times 39 \mu$, Reklaw Formation. 5, 6. Porocolpopollenites spp. (psilate-microreticulate). (p. B15).

5. D1852, slide 3 , coordinates $98.3 \times 18.0$, diameter $32 \mu$, Sparta Sand.

6. D1852, slide 2, coordinates, $83.5 \times 9.3$, diameter $32 \mu$, Sparta Sand.

7-9. Anacolosidites spp. (p. B15).

7. D1848, slide 2, coordinates $88.4 \times 11.6$, diameter $24 \mu$, Reklaw Formation.

8. D3421-B, slide 1 , coordinates $87.9 \times 10.6$, diameter $20 \mu$, Cook Mountain Formation.

9. D3421-B, slide 3, coordinates $78.3 \times 3.7$, diameter $19 \mu$, Cook Mountain Formation.

10-12. Ilexpollenites spp. (p. B15).

10. D1852, slide 2, coordinates $87.3 \times 2.9,30 \times 22 \mu$, Sparta Sand, high focus.

11. Same specimen, low focus.

12. D1852, slide 3 , coordinates $105.4 \times 12.6$, diameter $25 \mu$, Sparta Sand.

13,14. Echiperiporites spp. (p. B15).

13. D4383-A, slide 1, coordinates $109.7 \times 9.0$, diameter $34 \mu$, White Bluff Formation of Wilbert (1953).

14. D4383-B, slide 2, coordinates $110.6 \times 4.2$, diameter $32 \mu$, White Bluff Formation of Wilbert (1953).

15-19. Tricolporopollenites spp. (fusoid forms) (p. B15).

15. D1858, slide 5, coordinates $111.6 \times 8.0,32 \times 23 \mu$, Tallahatta Formation.

16. D1858, slide 6, coordinates $91.8 \times 11.2,28 \times 17 \mu$, Tallahatta Formation.

17. D3227, slide 1, coordinates $110.8 \times 17.6,27 \times 16 \mu$, Moodys Branch Formation. The specimens represented by figures 17-19 are perhaps most representative of this heterogeneous group.

18. D1848, slide 1, coordinates $113.1 \times 4.8,26 \times 15 \mu$, Reklaw Formation. Low focus.

19. Same specimen, high focus.

20-22. Multiporopollenites spp. (p. B15).

20. D1858, slide 5, coordinates $89.0 \times 5.0$, diameter $22 \mu$, Tallahatta Formation.

21. D1858, slide 5, coordinates $97.9 \times 10.6$, diameter $32 \mu$, Tallahatta Formation.

22. D1858, slide 5, coordinates $87.2 \times 5.9$, diameter $33 \mu$, Tallahatta Formation.

23, 24. Verrucatosporites spp. (p. B16).

23. D3699-A, slide 4, coordinates $101.4 \times 16.8,50 \times 35 \mu$, Yazoo Clay.

24. D3228, slide 1 , coordinates $109.2 \times 20.7,43 \times 31 \mu$, Cockfield Formation.

25-27. Carya spp. $29_{\mu-39 \mu}$ (p. B15).

25. D3697-B, slide 1, coordinates $98.1 \times 14.6,34 \times 40 \mu$, Yazoo Clay.

26. D3699-A, slide 1, coordinates $85.2 \times 7.3$, diameter $38 \mu$, Yazoo Clay. High focus.

27. Same specimen, low focus. 

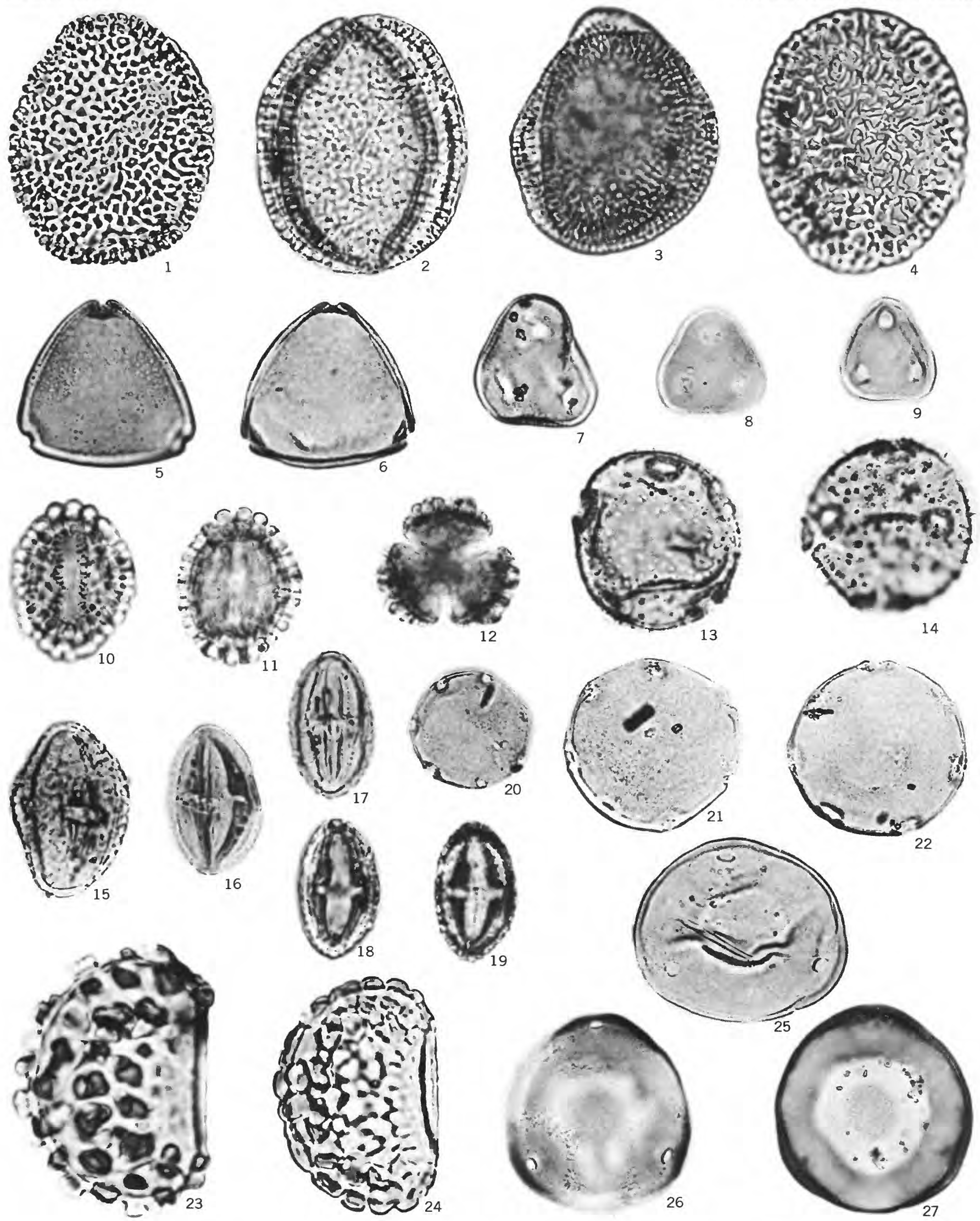

POLLEN AND SPORES FROM CLAIBORNE AND JACKSON GROUPS 


\section{PLATE 4}

[Magnification $\times 1,000$, figs. $1-35, \times 500$ figs. 36, 37]

Figures 1-3. Triatriopollenites sp. of the T. coryphaeus type $(13 \mu-18 \mu)$ (p. B16)

1. D1856, slide 2 , coordinates $78.6 \times 11.6$, diameter $14 \mu$, Zilpha Clay.

2. D1858, slide 5 , coordinates $91.5 \times 4.8$, diameter $17 \mu$, Tallahatta Formation.

3. D1858, slide 6 , coordinates $79.6 \times 6.4$, diameter $18 \mu$, Tallahatta Formation.

4, 5. Gothanipollis spp. (p. B16).

4. D4383-A, slide 1, coordinates $79.3 \times 21.6$, diameter $22 \mu$, White Bluff Formation of Wilbert (1953).

5. D1858, slide 3, coordinates $111.1 \times 9.1$, diameter $26 \mu$, Tallahatta Formation.

6,7. Tricolpopollenites spp. of the T. microhenrici type (p. B16).

6. D1852, slide 1, coordinates $91.4 \times 22.1,30 \times 16 \mu$, Sparta Sand.

7. D1852, slide 2, coordinates $87.3 \times 8.0,24 \times 17 \mu$, Sparta Sand.

8. 9. Porocolpopollenites spp. (verrucate) (p. B16).

8. D3224, slide 2 , coordinates $92.3 \times 13.6$, diameter $30 \mu$, Cockfield Formation.

9. D3224, slide 2, coordinates $101.4 \times 6.1$, diameter $23 \mu$, Cockfield Formation.

10,11. Tricolpopollenites spp. of the T. henrici type (p. B16).

10. D1852, slide 1 , coordinates $99.0 \times 19.8,37 \times 30 \mu$, Sparta Sand. High focus.

11. Same specimen, low focus.

12,13. Triatriopollenites sp. of the T. coryphaeus type $(20 \mu-30 \mu)$ (p. B16).

12. D1852, slide 2, coordinates $85.5 \times 17.7$, diameter $26 \mu$, Sparta Sand.

13. D1852, slide 3 , coordinates $81.7 \times 13.3$, diameter $27 \mu$, Sparta Sand.

14-17. Cyrillaceaepollenites cf. C. megaexactus (p. B17).

14. D4407-B, slide 2, coordinates $102.6 \times 6.2$, diameter $18 \mu$, Jackson Formation.

15. D4524, slide 1 , coordinates $91.6 \times 8.6$, diameter $17 \mu$, Cockfield Formation.

16. D4524, slide 1, coordinates $91.5 \times 8.6,15 \times 14 \mu$, Cockfield Formation.

17. D1856, slide 2 , coordinates $82.0 \times 2.6$, diameter $13 \mu$, Zilpha Clay.

18,19. Tricolporopollenites n. sp. B (Parthenocissus type) (p. B17).

18. D3228, slide 1, coordinates $84.0 \times 17.8,33 \times 26 \mu$, Cockfield Formation.

19. D3228, slide 1 , coordinates $84.2 \times 6.0,35 \times 24 \mu$, Cockfield Formation.

20,21. Cyrillaceaepollenites of the Pollenites ventosus type (p. B17).

20. D3699-A, slide 3, coordinates $82.6 \times 17.1$, diameter $17 \mu$, Yazoo Clay.

21. D4383-A, slide 1, coordinates $99.1 \times 5.0$, diameter $21 \mu$, White Bluff Formation of Wilbert (1953).

22, 23. Ephedra type A of Steeves and Barghoorn (p. B17).

22. D4383-A, slide 1, coordinates $78.0 \times 6.2,48 \times 22 \mu$, White Bluff Formation of Wilbert (1953).

23. D3699-A, slide 3, coordinates $101.2 \times 10.6,37 \times 18 \mu$, Yazoo Clay.

24-28. Tricolporopollenites cingulum (p. B17).

24. D1858, slide 5 , coordinates $111.3 \times 16.3,21 \times 14 \mu$, Tallahatta Formation.

25. D1858, slide 5, coordinates $111.3 \times 16.3,21 \times 9 \mu$, Tallahatta Formation.

26. D1858, slide 5 , coordinates $114.2 \times 18.5,17 \times 11 \mu$, Tallahatta Formation.

27. D3227, slide 1, coordinates $105.8 \times 12.4,18 \times 11 \mu$, Moodys Branch Formation. Low focus.

28. Same specimen, high focus.

29, 30. Multiporopollenites sp. of the Dorstenia type (p. B17).

29. D3699-A, slide 3, coordinates $81.4 \times 3.4,21 \times 18 \mu$, Yazoo Clay.

30. D3699-A, slide 3, coordinates $77.7 \times 5.1,24 \times 23 \mu$, Yazoo Clay.

31-33. Tricolpopollenites liblarensis (p. B18).

31. D1854, slide 2, coordinates $112.5 \times 8.3,17 \times 12 \mu$, Wilcox Formation (formerly Ackerman Formation).

32. D1852, slide 1 , coordinates $90.6 \times 19.9,14 \times 8 \mu$, Sparta Sand.

33. D1856, slide 2, coordinates $80.3 \times 1.9,20 \times 10 \mu$, Zilpha Clay.

34,35. Graminidites spp. (p. B17).

34. D4407-B, slide 2, coordinates $105.7 \times 10.6,42 \times 40 \mu$, Jackson Formation.

35. D4383-A, slide 1, coordinates $80.30 \times 6.4,37 \times 28 \mu$, White Bluff Formation of Wilbert (1953).

36, 37. Peltate leaf hairs of Engelhardtia.

36. D4407-B, slide 2, coordinates $86.8 \times 5.5,100 \times 86 \mu$, Jackson Formation ( $\times 500$ ).

37. D4383-B, slide 3, coordinates $77.3 \times 13.1,94 \times 86 \mu$, White Bluff Formation of Wilbert $(1953)(\times 500)$. 

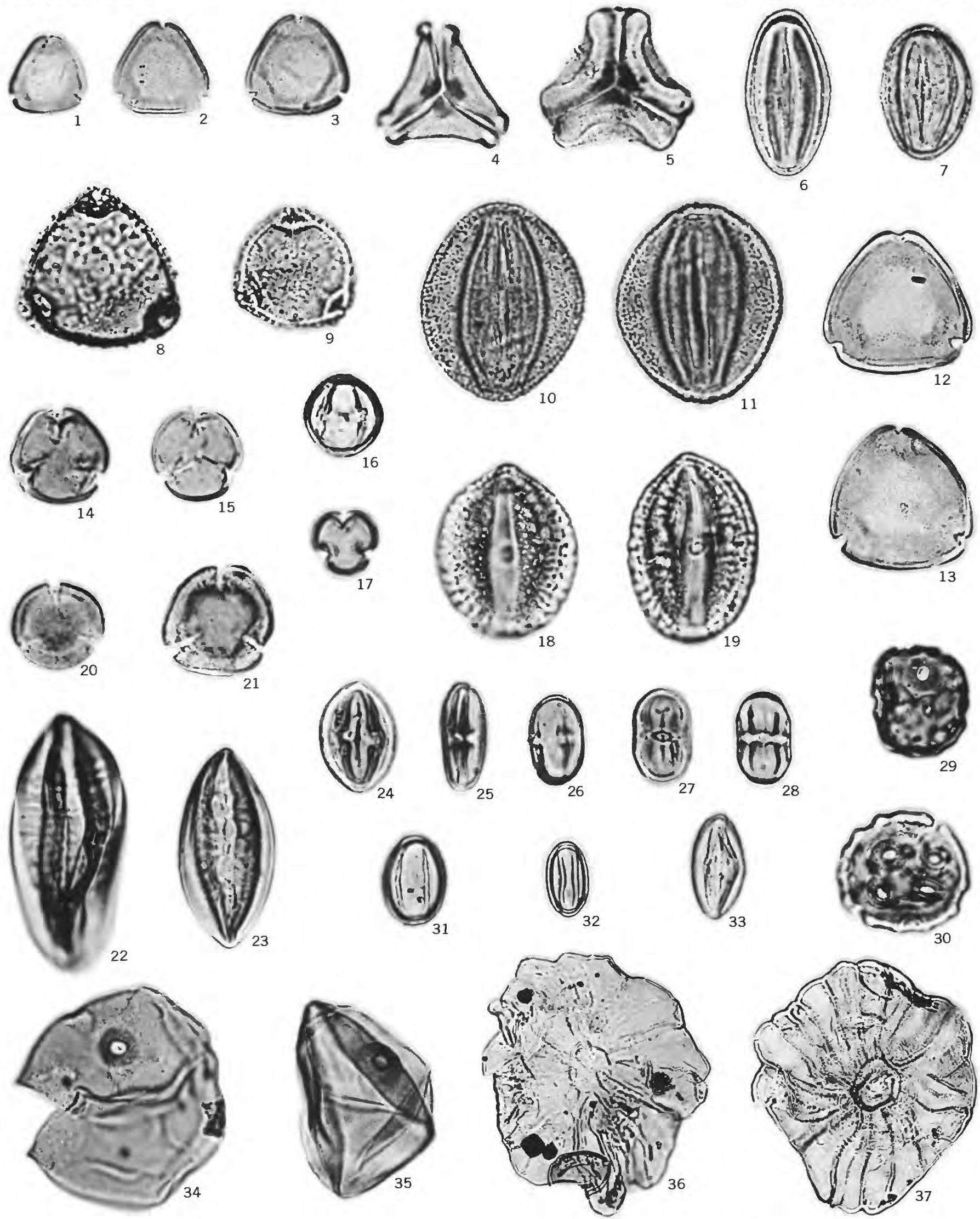

POLLEN AND SPORES FROM CLAIBORNE AND JACKSON GROUPS 